TI $2011-095 / 1$

Tinbergen Institute Discussion Paper

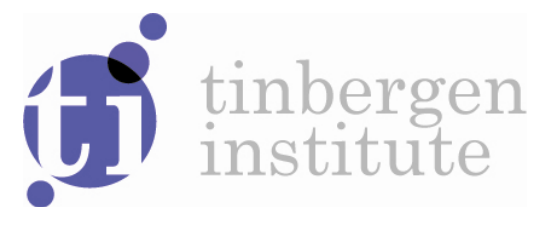

\title{
The Deterrence Effects of U.S. Merger Policy Instruments
}

Joseph A. Clougherty

Jo Seldeslachts ${ }^{2}$

1 University of Illinois at Urbana-Champaign, USA, and CEPR-London;

2 Faculty of Economics and Business, University of Amsterdam, and Tinbergen Institute, The Netherlands. 
Tinbergen Institute is the graduate school and research institute in economics of Erasmus University Rotterdam, the University of Amsterdam and VU University Amsterdam.

More TI discussion papers can be downloaded at http://www.tinbergen.nl

Tinbergen Institute has two locations:

Tinbergen Institute Amsterdam

Gustav Mahlerplein 117

1082 MS Amsterdam

The Netherlands

Tel.: +31(0)205251600

Tinbergen Institute Rotterdam

Burg. Oudlaan 50

3062 PA Rotterdam

The Netherlands

Tel.: +31(0)10 4088900

Fax: +31(0)104089031

Duisenberg school of finance is a collaboration of the Dutch financial sector and universities, with the ambition to support innovative research and offer top quality academic education in core areas of finance.

DSF research papers can be downloaded at: http://www.dsf.nl/

Duisenberg school of finance

Gustav Mahlerplein 117

1082 MS Amsterdam

The Netherlands

Tel.: +31(0)20 5258579 


\title{
The Deterrence Effects of U.S. Merger Policy Instruments
}

\author{
Joseph A. Clougherty * \\ University of Illinois at Urbana-Champaign, and CEPR-London \\ 350 Wohlers Hall; 1206 S. $6^{\text {th }}$ St., MC-706; Champaign, IL 61820; USA \\ E-Mail: jaclough@illinois.edu \\ Tel: +1 2173336129 \\ Jo Seldeslachts \\ University of Amsterdam \\ Roetersstraat 11, 1018 WB, Amsterdam, The Netherlands \\ E-Mail: J.W.Seldeslachts@uva.nl \\ Tel: +31 205257158
}

July 4, 2011

\begin{abstract}
We estimate the deterrence effects of U.S. merger policy instruments with respect to the composition and frequency of future merger notifications. Data from the Annual Reports by the U.S. DOJ and FTC allow industry based measures over the 1986-1999 period of the conditional probabilities for eliciting investigations, challenges, prohibitions, court-wins and court-losses: deterrence variables akin to the traditional conditional probabilities from the economics of crime literature. We find the challenge-rate to robustly deter future horizontal (both relative and absolute) merger activity; the investigation-rate to slightly deter relativehorizontal merger activity; the court-loss-rate to moderately affect absolute-horizontal merger activity; and the prohibition-rate and court-win-rate to not significantly deter future horizontal mergers. Accordingly, the conditional probability of eliciting an antitrust challenge (i.e., remedies and prohibitions) involves the strongest deterrence effect from amongst the different merger policy instruments.
\end{abstract}

JEL: L40, L49, K21

* Corresponding author. We wish to thank Al Klevorick and two anonymous referees for helpful comments; Tomaso Duso, William Kovacic, Tobias Kretschmer, Francisco Marcos, Sam Peltzman, Juan Santaló and Paul Zimmerman for helpful discussions; and participants from the IE Seminar, the ' $16^{\text {th }}$ WZB Conference on Markets and Politics and $2{ }^{\text {nd }}$ Conference of the Research Network on Innovation and Competition Policy (RNIC)', the 2009 IIOC Conference in Boston, the $5^{\text {th }}$ ACLE Conference on 'To Enforce and Comply: Incentives Inside Corporations and Agencies', and the ZEW Conference on 'Ex-post Evaluation of Competition Policy' for helpful feedback. Enno Schroeder and Claudia Baldermann provided excellent research assistance. Jo Seldeslachts recognizes financial assistance from the Research Network on Innovation and Competition Policy (RNIC) and the EU $7^{\text {th }}$ Framework Program for Research. 


\section{Introduction}

"We firmly believe that deterrence is perhaps the single most important ultimate outcome of the Division's work ... [but] ... we have not attempted to value either the "spillover" effects or the deterrent effects of our successful enforcement efforts, though we and those who have written on the subject believe that such effects exist and are significant" (Antitrust Division, U.S. Department of Justice, in Nelson and Sun 2001, 939-940).

As the above quotation indicates, merger policy entails not only direct regulatory effects but also indirect deterrence effects, as effective policy puts a premium on firms internalizing antitrust rules in their decision making. Merger policy should then create incentives that shape the behavior of both firms found - and not found - in violation of these rules, as no policy can be effective if its every application has to be policed (Wilks 1996; Baker 2003). Accordingly, the effects of merger policy are not limited to the specific firms targeted by an antitrust investigation, but include all firms whose behavior and performance would be affected in the future by specific decisions. Joskow (2002, 99-100) takes the next step by noting "that the test of a good legal rule is not primarily whether it leads to the correct decision in a particular case, but rather whether it does a good job deterring anticompetitive behavior”.

Yet, measuring the deterrence effects of merger policy has proven to be quite challenging. A number of scholars (e.g., Allen 1984; Eckbo 1989; Nelson and Sun 2001;

Crandall and Winston 2003) have pointed out the difficulties involved with eliciting deterrence effects - including the challenge of identifying counterfactuals (e.g., mergers not proposed or not proposed in a certain fashion due to the existence of antitrust). For instance, the U.S. Department of Justice (DOJ) and U.S. Federal Trade Commission (FTC) have not factored any beneficial deterrence effects resulting from merger policy as they have been unable to approach measurement (Nelson and Sun 2001). This measurement omission is all the more striking when one considers that the two antitrust agencies firmly believe the deterrence of anti-competitive merger filings to be considerable (see the introductory quote above); and moreover, the agencies are required by the 'Government Performance and Results Act' (GPRA) to estimate the consumer savings derived from antitrust policies. 
Despite the importance of this subject, we are unaware of any scholarship attempting to measure merger policy deterrence while employing the dominant deterrence methodology from the crime-and-punishment literature spawned by Becker (1968). Such an omission is all the greater in that the conditional probabilities methodology from the economics of crime literature rests on strong theoretical foundations (Becker 1968; Ehrlich 1973), has been subject to a great deal of scholarship (see Cameron 1988, 1994; Grogger 1990; Cloninger and Marchesini 2006 for reviews), and has elicited a healthy amount - particularly with regard to capital punishment and the deterrence of homicides - of criticism (e.g., Passel and Taylor 1977; Klevorick, 1995; Berk 2005; Donohue and Wolfers 2005). Accordingly, the methodological framework from the economics of crime literature provides a sound means to factor changes in the tenor of U.S. merger policy that allows for more specific analysis of merger policy instruments by moving beyond the before/after and having/not-having comparisons indicative of previous work on merger policy deterrence. In particular, the conditional probabilities of detection, conviction and punishment (as well as severity of punishment) from the economics of crime literature lend themselves well to the realm of merger policy with its somewhat equivalent conditional probabilities of eliciting investigations, challenges, prohibitions, court-wins, and court-losses. ${ }^{1}$

We employ the conditional probabilities approach from the economics of crime literature to investigate whether different merger policy instruments (investigations, remedies, prohibitions and court-cases) entail deterrence effects with regard to the composition of proposed merger activity in U.S. industrial sectors. In particular, we combine the conditional probabilities approach with two previously employed methodological means for measuring deterrence: 1) considering changes in the composition - horizontals versus non-horizontals - of proposed merger activity (Stigler, 1966; Scherer, 1980; Allen, 1984); 2) discerning departures from the merger wave as a manifestation of deterrence (Seldeslachts et al. 2009). ${ }^{2}$ Empirically,

\footnotetext{
${ }^{1}$ The standpoint of US antitrust is taken; thus, a win (loss) means the US government won (lost) the court case. ${ }^{2}$ Two additional means to measuring deterrence: 1) detecting differences in rival-firm stock-prices (e.g., Eckbo and Wier 1985; Eckbo 1992); 2) surveying antitrust lawyers (Deloitte and Touch 2007; Twynstra Gudde 2005).
} 
we use two-digit industrial sector data reported by the DOJ and FTC for the 1986-1999 period, and employ panel-data techniques in order to infer whether our deterrence variables lead to relatively fewer horizontal mergers in subsequent years.

Our results suggest that increasing the challenge-rate (i.e., the conditional probability of eliciting an antitrust action - a remedy or prohibition - with respect to eliciting an investigation) involves significant and robust deterrence of future horizontal merger activity. Furthermore, increasing the investigation-rate (i.e., the probability of eliciting a secondrequest-investigation) and lowering the court-loss-rate (i.e., the probability that DOJ/FTC lose a court case) somewhat deter future merger activity. The results also indicate that increasing the severity of the antitrust action (i.e., the conditional probability of eliciting a prohibition with respect to eliciting an antitrust action) does not involve significant deterrence effects; in other words, prohibitions - while involving deterrence - do not generate any additional deterrence above and beyond remedies. Finally, increasing the court-win-rate (i.e., the probability that DOJ/FTC win a court case) also does not involve significant deterrence.

In order to support our analysis, the structure of the paper is as follows. To point out the methodological practices upon which we either build or improve upon in our empirical analysis, section 2 reviews the literature on merger policy deterrence while section 3 reviews the economics of crime literature. Section 4 describes our industrial sector data on merger policy and M\&A activity. Section 5 discusses issues and techniques with regard to our dynamic panel data estimation. Section 6 presents empirical results. Section 7 concludes.

\section{Merger Policy Deterrence}

The pre-existing literature on merger policy deterrence involves four particular properties that we draw and build upon with our empirical approach. In particular, when we elicit U.S. merger policy deterrence effects, we (1) improve upon the broad level-of-analysis employed by

previous work by moving the analysis to the industrial sector level; (2) move beyond the 
customary before/after and having/not-having comparisons and make some inferences with regard to the deterrence effects of particular merger policy instruments; (3) test for both composition-based deterrence (the ratio of horizontal mergers to total mergers) and frequencybased deterrence (the number of horizontal and non-horizontal mergers); and (4) control for common drivers of merger waves to help ensure robust causal inferences.

First, one characteristic of the scant literature on merger policy deterrence is the relatively broad level of analysis employed in most studies. For instance, Eckbo (1992) compares the U.S. and Canadian merger populations (during a period lacking Canadian antitrust enforcement) to gather whether the stock-prices of U.S. non-merging (rival) firms are significantly less than those in Canada. He finds the rivals of Canadian mergers to have abnormal returns no greater than those of U.S. mergers, thus suggesting a lack of deterrence as Canadian mergers were no more anti-competitive than U.S. mergers. Stigler (1966) also looked for a change in the general composition of U.S. merger activity in the years following the 1950 anti-merger amendment to the Clayton Act; in particular, Stigler finds a trend away from horizontal merger activity. We attempt to improve upon this previous work in merger policy deterrence by considering deterrence effects at the industrial sector level-of-analysis.

Second, the broad level of analysis employed in previous work also lent itself to empirical studies making broad comparisons. For instance, Eckbo and Wier (1985) make use of the period prior to and after the onset of the U.S. Hart-Scott-Rodino (HSR) Act to gather whether that statute led to fewer anti-competitive mergers. Such results naturally generate implications for whether merger policy in general - or a particular shift in a policy regime yields more or less deterrence; yet, targeted implications regarding the effectiveness of different merger policy instruments are challenging with such a set-up. Only the recent Seldeslachts et al. (2009) study considers the effectiveness of different merger policy tools with respect to deterring future mergers. Yet that study suffers from a broad nationwide level-ofanalysis; e.g., the impact of a spike in a nation's annual antitrust activity is considered on the 
overall number of national mergers in subsequent years. Accordingly, we will consider the impact of merger policy tools on future merger proclivities, but be able to do so at a more narrow level-of-analysis. Hence, we will tie the use of these different merger policy tools to future merger behavior in the particular industrial sector.

Third, the previous literature indicates two principal forms via which merger deterrence potentially manifests: (1) frequency-based deterrence, as merger plans are forsaken due to the existence (or enhancement) of antitrust; (2) composition-based deterrence, as future mergers are modified and shaped differently to conform with antitrust regulations (Aaronson, 1992). Beginning with Stigler (1966), a few researchers (Scherer 1980; Allen 1984) have considered the composition of proposed mergers (horizontal with respect to total mergers) to gather whether antitrust laws or administration changes yield deterrence in the form of altered merger types. The Eckbo (1992) and Eckbo and Wier (1985) approach is also firmly grounded in composition-based deterrence, as larger abnormal-returns for rival firms indicate more marketpower based merger activity. On the other hand, the Seldeslachts et al. (2009) study is firmly rooted in frequency-based deterrence, as they consider the impact of spikes in antitrust actions on the future level of merger notifications. We initially follow the Stigler approach and consider the ratio of horizontal mergers to total mergers in an industrial sector while keeping in mind that the population of anti-competitive mergers resides within horizontal mergers—at least in the eyes of the DOJ and FTC. ${ }^{3}$ In addition to the Stigler approach, we go beyond strictly considering composition effects to also consider the frequencies of horizontal and nonhorizontal mergers in order to ensure that it is the deterrence of horizontals - and not the encouragement of non-horizontals - that is behind any measurable deterrence.

Fourth, despite the fact that mergers have long been realized to manifest in waves (Gort 1969; Golbe and White 1993), much of the research in economics has not considered merger

\footnotetext{
${ }^{3}$ In compiling our data, we read through all of the annual reports by the DOJ and FTC summarizing their antitrust activities regarding merger control (1986-2005, although we use only 1986-1999 in our empirical analysis due to matching with industry data and the switch to NAICS after 1999) and in only two merger cases did we find vertical concerns as a rationale behind antitrust scrutiny.
} 
activity in its proper wave-like context. Research in finance economics (Andrade and Stafford 2004; Harford 2005; Rhodes-Kropf et al. 2005), however, has advanced our understanding of merger-wave drivers. Furthermore, holding the wave constant was a crucial feature in the Seldeslachts et al. (2009) set-up, as their deterrence manifested as departures in the number of merger notifications from the merger wave. Our industrial sectors will also be subject to merger waves, accordingly we will control for common drivers of merger activity from the recent finance economics literature. In addition, we will employ fixed period effects and dynamic panel data models in order to fully control for waves as we also capture deterrence by the departure of merger activity from the merger wave.

\section{Economics of Crime}

Our empirical approach to eliciting the deterrence effects of U.S. merger policy instruments draws and improves upon the following properties from the economics of crime literature. First, invoking that literature yields a more theoretically consistent empirical set-up by focusing on the relevant conditional probabilities. Second, the extensive empirical literature on crimeand-punishment deterrence yields a number of best empirical practices; i.e., the need to consider the inter-connectedness of data observations over time. There, we can use the current state-of-the-art deterrence practice to cluster standard errors, but also improve upon that practice by employing dynamic panel data models and introducing control constructs that drive merger waves. Third, we will employ instrumental variable techniques using the GMM System estimator to deal not only with clear endogeneity in the lagged dependent variables, but also potential endogeneity in the deterrence and merger-wave variables.

First, Becker (1968) and Ehrlich’s (1973) seminal work on the economics of crime generated an extensive amount of empirical literature employing a choice-theoretic framework. While some variations in the design exist, most subsequent empirical pieces have crime depending upon the following conditional probabilities (i.e., deterrence variables): detections 
over the number of crimes, convictions over the number of detections, punishments over the number of convictions, and then the severity of the punishment (e.g., Dezhbakhsh, Rubin and Shepherd 2003; Katz, Levitt and Shustorovich 2003; Mocan and Gittings 2003; Zimmerman 2004). This set-up derives from theory as the deterrence variables capture the relevant subjective probabilities that offenders are detected, convicted, and punished - as well as the severity of the punishment. In short, a crime supply equation is formulated as the deterrence variables play the role of prices with lower prices signaling a greater net relative gain from engaging in offences. We can formulate a somewhat similar equation for the provision of horizontal mergers employing conditional probabilities that conform with this dominant empirical approach to deterrence. Given that anti-competitive mergers are a subset of the number of proposed horizontal mergers and that U.S. antitrust actions almost exclusively target horizontal mergers, we formulate five deterrence variables that capture the relevant conditional probabilities. Accordingly, this yields a more theoretically consistent approach to measuring changes in the tenor of merger policy than the various ad-hoc means previously employed.

Second, an additional benefit of invoking the extensive literature on crime-andpunishment is the wealth of scholarship on the appropriate econometric practices with respect to measuring deterrence, as this can provide an informed basis upon which to structure our study. For one, Donohue and Wolfers (2005) point out that it is standard practice in the deterrence literature to cluster standard errors by the relevant panel grouping. Thus, there seems to be some implicit understanding in the literature that periods are inter-connected (e.g., Zimmerman 2009). Related to the previously noted wave-like properties of merger activity, we are particularly conscious of the underlying dynamics and the potential for serial correlation. Beyond simply clustering standard errors, however, we will address this concern more directly by including common drivers of merger waves and by using a dynamic panel data framework. While including lagged dependent variables controls for auto-regressive processes and helps ameliorate autocorrelation concerns, dynamic panel data models lead to biased and inconsistent 
estimates due to the obvious correlation of the lagged dependent variable(s) with the error term. Accordingly, we employ Arellano and Bover's (1995) system generalized method of moments (System GMM) estimator for dynamic panel data. GMM instruments for lagged dependent variables - as well as all other potentially endogenous variables - and yields unbiased and consistent estimators; thus, it generates good results when dealing with auto-regressive processes in panel data. In fact, Bertrand et al. $(2004,274)$ state in their conclusion that "We also hope that our study will contribute in generating further work on alternative estimation methods ... such as GLS or GMM estimation of dynamic panel data models”. Accordingly, controlling for merger waves, invoking a dynamic panel data model, and employing GMMcollectively improve upon the efforts in the economics of crime literature by more properly addressing the issue of inter-connectedness over time.

Third, the potential endogeneity of conditional probability variables has been recognized early on in the literature. Ehrlich (1973) noted that the probability and severity of punishment are not necessarily exogenous as they are potentially determined by crime levels. Given that investigations, remedies, prohibitions, court-wins and court-losses are likely to be a function of the number of mergers, our deterrence variables are also potentially endogenous. Yet beyond simultaneity resides an additional source of potential endogeneity for the first deterrence variable - the detection-rate, or investigation-rate in our context - that is endemic to the crime-and-punishment literature. A number of scholars (e.g., Klein, Forst and Filatov 1978; Avio 1988; Donohue and Wolfers 2005) have recognized that the detection-rate (with the number of crimes in the denominator) is endogenous by design since the dependent variable includes the number of crimes in the numerator. In particular, this linked-variable construction can produce biased coefficient estimates in the presence of measurement error that lead to an artificial negative coefficient-estimate for the detection-rate variable. In order to deal with the above endogeneity concerns, scholars have begun to lag the deterrence variables (e.g., Katz et al. 2003) and use instrumental variable techniques (e.g., Dezhbakhsh et al. 2003; Donohue and 
Wolfers 2005). Accordingly, it behooves us to both lag our deterrence variables and fully employ System GMM by instrumenting not only for clearly endogenous lagged dependent variables, but also for the potentially endogenous deterrence variables (as well as the mergerwave control variables).

\section{Dataset}

The data are panel in nature and consist of matching observations from two separate sources: the DOJ and FTC’s combined 'Annual Report to Congress on Hart-Scott-Rodino Antitrust Enforcement'; and Compustat's North American database. These data sources were compiled to yield measures of U.S. M\&A activity, merger policy actions and merger-wave controls at the two-digit SIC sector level (seventy sectors) on an annual basis (the 1986-1999 period). Accordingly, each panel consists of a two-digit SIC sector; for instance, 'Tobacco Products' is one distinct panel consisting of eleven annual observations (1990-1999). ${ }^{4}$ While more specific sector data (such as five-digit level SIC data) would be desired, U.S. antitrust authorities publicly report data only at the two-digit level. Hence, the above represents the best publicly available data on U.S. merger enforcement suitable for a deterrence study. ${ }^{5}$

First, the FTC and DOJ data yield measures of M\&A activity and merger policy actions for U.S. industrial sectors. With regard to M\&A activity, we have the annual number of horizontal mergers, non-horizontal merges and total mergers - where total is composed of both

\footnotetext{
${ }^{4}$ While we have and employ data from 1986-1999, the data points from 1986-1989 do not constitute actual observations due to the autoregressive nature of the econometric specifications and the need to employ lagged values as instruments.

${ }^{5}$ See Coate, Higgins and McChesney (1990) and Coate (2005) for studies based on non-public data from internal U.S. antitrust files. While more specific in nature, such data are both unobtainable for those not employed by the antitrust agencies and, moreover, not necessarily suitable for a deterrence study. Nevertheless, an early debate (Long, Schramm and Tollison, 1973; Siegfried, 1975; Preston and Connor, 1992) on the implications of disaggregated data for general antitrust policy finds broad industry aggregation to bias statistical results downward: i.e., makes it more-not less—difficult to detect causal patterns. Thus, our results would then represent a lower-bound in concerns of capturing deterrence effects. Furthermore, firms may also calculate their perceived probabilities of eliciting an antitrust action based on a broader level-of-analysis than the 2-digit level; i.e., based on divisional-level or nation-wide levels. Nevertheless, unreported tests that include divisional-level conditional probabilities along with two-digit level probabilities suggest the relevance of the two-digit level for this empirical context. Yet it remains an open question for future work as firms may calculate their conditional probabilities based on developments and experiences of their own, of the immediate industry, of related industries, of the economy as a whole, and/or a combination of the above.
} 
horizontal and non-horizontal transactions - by industrial sector (hereafter respectively referred to as Horizontal, Non-Horizontal and Total Mergers). It is important to point out that horizontal mergers are defined as mergers where both the target and acquirer belong to the same four-digit SIC industry; therefore, the definition of a horizontal merger is more specific even though the data is aggregated to the two-digit level by U.S. authorities. ${ }^{6}$ As previously noted, mergers in industrial sectors evolve in waves. Figure 1 - based on the eventual observations employed in the empirical estimations - charts the average number of Total Mergers per sector from 19891999 and illustrates the wave-like pattern in which mergers manifest; though it should be noted that our sample does not exhibit a complete wave: capturing the early-1990s trough (and a few pre-trough observation years) and the 1997/1998 peak (and a few post-peak observation years). The wave-like nature of merger activity will be important when setting up our empirical specification; hence, the importance of our second data source.

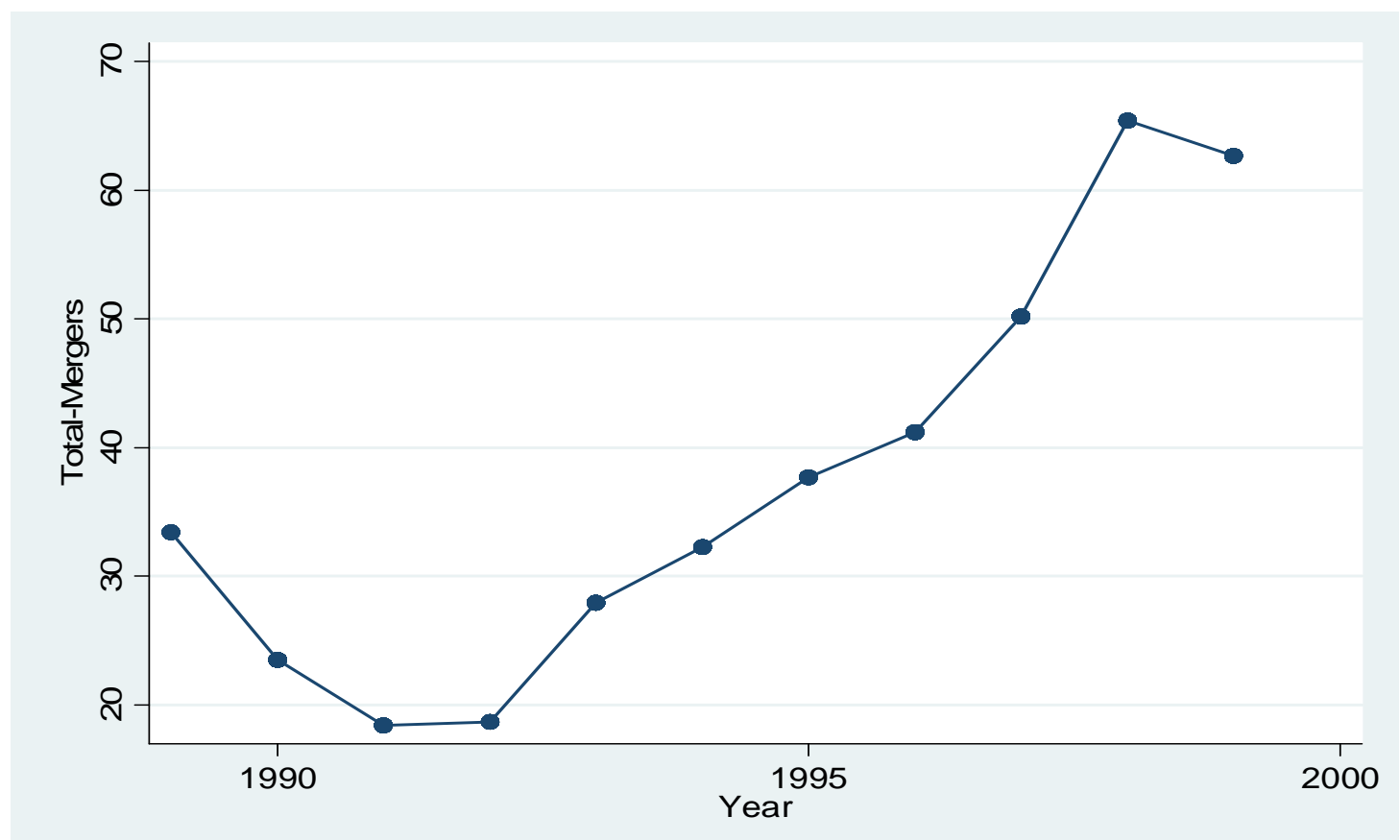

Figure 1. The Average Number of ‘Total Mergers’ Per Industry (1989-1999)

\footnotetext{
${ }^{6}$ Accordingly, non-horizontal mergers are where the acquirer belongs to a different 4-digit industry to that of the target firm. The antitrust authorities do note, however, that in a few instances 3-digit correspondence is used to define horizontal mergers. See Table 1 for an exact definition of all the variables we employ.
} 
We have two-digit level data on the total number of DOJ and FTC second request investigations, remedies, prohibitions, court-wins and court-losses. While the annual number of second-request-investigations by industry is reported by the FTC and DOJ in their combined 'Annual Report to Congress on Hart-Scott-Rodino Antitrust Enforcement', the additional merger policy actions (remedies, prohibitions, court-wins and court-losses) are not. ${ }^{7}$ Thus, we went through the annual reports and assigned a two-digit SIC code to each noted merger case where a complaint or injunctive relief was filed in a U.S. district court by the FTC or DOJ, and gathered information on the outcome of the case (e.g., clearance, remedy or prohibition). Furthermore, we were then able to compile this data into counts of the number of annual remedies and prohibitions applied in a particular two-digit industry.

In our empirical setting (where the Hart-Scott-Rodino merger review process operates), a premium is put on speedy resolution of the matter with either a negotiated settlement being found between the merging parties and the antitrust authority (a remedy) or a prohibition intent is announced and merging parties then abandon the merger transaction. ${ }^{8}$ Accordingly, a prohibition in our empirical context reflects the intent of antitrust authorities, and not necessarily the ultimate outcome via the courts. Court cases and consequent verdicts come about when merging firms and the government cannot come to an agreement: such cases are thus subsequent to the initial action - or intent - of antitrust authorities. We were able to identify any verdicts in court cases regarding antitrust authority intent to prohibit - or seriously remedy - a merger proposal. ${ }^{9}$ More specifically, we compiled this data into counts of verdicts

\footnotetext{
${ }^{7}$ For the 1997-2007 reports see http://www.ftc.gov/bc/anncompreports.shtm .

${ }^{8}$ Abandonments occurring after second-request-investigations were considered equivalent to prohibitions, as they effectively lead to the same outcome: the full prevention of a merger.

${ }^{9}$ Beyond the 'Annual Report to Congress on Hart-Scott-Rodino Antitrust Enforcement' we also used the individual FTC and DOJ Annual reports (sometimes more comprehensive in listing cases) and the websites of the agencies in order to gather information on the ultimate outcome(s) of cases. These additional sources - and searches of media outlets - were sometimes particularly useful in determining the dates and outcomes for court cases. Three independent and separated 'sets of eyes' were employed in categorizing the various merger cases into the appropriate industries and antitrust outcomes: first a research assistant, then one co-author, and then the other co-author. Any inconsistencies were resolved amongst the three data compilers.
} 
confirming (a court-win) or countering (a court-loss) antitrust authority intent in a particular two-digit industry. ${ }^{10}$

Our main goal is to investigate whether different merger policy instruments have an impact on the composition of future merger activity. Following Stigler's (1966) seminal work and given that U.S. antitrust authorities almost exclusively target horizontal mergers, the relevant question in more precise terms is whether merger policy actions in targeted sectors lead to relative reductions in horizontal mergers in those particular sectors. Therefore, our main construct of interest is the annual number of horizontal mergers relative to the total number of mergers in an industrial sector (hereafter referred to as Relative-Horizontals).

For our main explanatory variables, we adapt the conditional probability approach from the crime-and-punishment literature to the context of U.S. merger policy. At the two-digit level, we construct five conditional probabilities (the five deterrence variables); first, the number of investigations over the number of horizontal mergers (Investigation-Rate); second, the number of antitrust actions over the number of investigations (Challenge-Rate); third, the number of prohibitions over the number of antitrust actions (Prohibition-Rate); fourth, the number of antitrust court-wins over the lagged number of prohibitions (Court-Win-Rate); fifth, the number of antitrust court-losses over the lagged number of prohibitions (Court-Loss-Rate). Given the linked variable construction between Investigation-Rate - horizontal mergers in the denominator - and Relative-Horizontals, and given that antitrust activity undertaken is likely a function of the number of mergers, lagging the deterrence variables represents a sound first step in avoiding endogeneity. Accordingly, we lag the five conditional probabilities to mitigate simultaneity-based endogeneity concerns. More specifically, we follow Leary (2002) and Seldeslachts et al. (2009) by employing a lagged two-year average for our conditional

\footnotetext{
${ }^{10}$ Some mergers received multiple post-HSR-process verdicts as they made their way through different courts of appeal, thus each individual verdict is considered to be either a court-win or court-loss for antitrust.
} 
probabilities. ${ }^{11}$ The rationale behind employing a two-year average owes in part to the FTC considering its enforcement efforts to yield deterrence benefits for two years (Davies and Majumdar 2002). An additional advantage of this definition is that it de-sensitizes the deterrence variables to yearly variations (Leary 2002). ${ }^{12}$

We also constructed annual industry-level control variables over the period of study from Compustat's North America database - a database containing firm-specific information on about 22,000 publicly listed U.S. firms. Such controls are pivotal for our analysis, as finance economics scholars (e.g., Andrade and Stafford 2004; Harford 2005) have found industryfactors to be important drivers of merger waves. In keeping with this literature, we constructed annual measures of concentration, sales growth and cash flow for each two-digit industry; see Table 1 for an exact definition of all variables. Including these industry specific variables should further control - in addition to employing a dynamic panel data framework - for cyclical movements in mergers. Table 2 reports summary statistics - based on the observations employed in the empirical estimations - for the merger, deterrence and control variables.

\footnotetext{
${ }^{11}$ For example, the value for the Investigation-Rate ${ }_{\mathrm{t}}$ in one particular observation year is the following: ((Investigations $\mathrm{t}_{\mathrm{t}}+$ Investigations $_{\mathrm{t}-1}$ ) / ( Horizontal-Mergers $\mathrm{t}_{\mathrm{t}}+$ Horizontal-Mergers $\left._{\mathrm{t}-1}\right)$ ))

${ }^{12}$ Auxiliary regression estimations that also include additional lags of the deterrence variables support the relevance of a two-year (and not a three-year) window in order to measure the different conditional probabilities.
} 


\section{Table 1. Description of Variables Used in the Regressions}

Variable

HORIZONTALS $_{\mathrm{t}}$

NON-

HORIZONTALS $_{\mathrm{t}}$

TOTAL-MERGERS

RELATIVE-

HORIZONTALS $_{\mathrm{t}}$

\section{Description}

Log of the yearly number of horizontal mergers (+1 for zero) in a SIC-2 industry $i$. 'Horizontal' defined as target and acquirer from same industry at the SIC-4 level $\in$ SIC-2 industry $i$.
Log of the yearly number of non-horizontal mergers (+1 for zero) in a SIC-2 industry $i$. 'Nonhorizontal' defined as acquirer coming from a different SIC4 industry than target's SIC-4 industry $\in$ SIC-2 industry $i$.

Log of the total yearly number of mergers (+1 for zero) in a SIC-2 industry $i$. 'Total-Mergers' defined as all mergers where targets belong to a SIC-4 industry $\in$ SIC-2 industry $i$.

The yearly number of horizontal mergers as a percentage of the yearly number of total mergers in a SIC-2 industry $i$. 'Horizontal' defined as target and acquirer sharing same SIC-4 level industry $\in$ SIC2 industry $i$. 'Total-Mergers' defined as all mergers where targets belong to a SIC-4 industry $\in$ SIC-2 industry $i$.
INVESTIGATION-
Two-year sum of FTC and DOJ second request investigations ('investig') over two-year sum of RATE $_{\mathrm{t}}$ horizontal mergers in SIC-2 industry i,

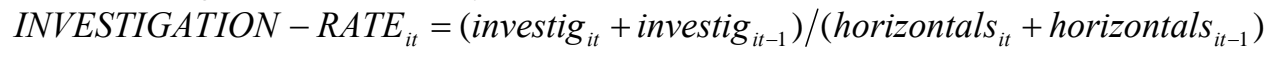
CHALLENGE- RATE $_{t}$
Two-year sum of FTC and DOJ remedies ('remed') and prohibitions ('proh') that were filed through a U.S. district court over two-year sum of second request investigations ('investig') in SIC-2 industry $i$, CHALLENGE - RATE $E_{i t}=\left(\right.$ remed $_{i t}+\operatorname{remed}_{i t-1}+\operatorname{proh}_{i t}+$ proh $\left._{i t-1}\right) /\left(\right.$ investig $_{i t}+$ investig $\left._{i t-1}\right)$

PROHIBITIONRATE $_{\mathrm{t}}$

Two-year sum of FTC and DOJ prohibitions ('proh') over two-year sum of FTC and DOJ remedies ('remed') and prohibitions ('proh') - that were filed through a U.S. district court - in SIC-2 industry $i$, PROHIBITION - RATE $_{i t}=\left(\right.$ proh $\left._{i t}+\operatorname{proh}_{i t-1}\right) /\left(\operatorname{remed}_{i t}+\operatorname{remed}_{i t-1}+\right.$ proh $_{i t}+$ proh $\left._{i t-1}\right)$

COURT-WIN-RATE $\mathrm{t}_{\mathrm{t}}$ Two-year sum of FTC and DOJ cases won in court ('win') over two-year sum of FTC and DOJ prohibitions ('proh'), lagged two years, in SIC-2 industry $i$,

$$
W I N-R A T E_{i t}=\left(\text { win }_{i t}+\text { win }_{i t-1}\right) /\left(\text { proh }_{i t-2}+\text { proh }_{i t-3}\right)
$$

COURT-LOSSRATE $_{\mathrm{t}}$ Two-year sum of FTC and DOJ cases lost in court ('loss') over two-year sum of FTC and DOJ prohibitions ('proh'), lagged two years, in SIC-2 industry $i$,

$$
L O S S-R A T E_{i t}=\left(\operatorname{loss}_{i t}+\operatorname{loss}_{i t-1}\right) /\left(\text { proh }_{i t-2}+\text { proh }_{i t-3}\right)
$$

$\mathrm{HHI}_{\mathrm{t}}$

Log of the Herfindahl index for the average of SIC-4 industries that constitute the relevant SIC-2 industry; i.e. for SIC-2 industry $i, H H I_{i t}=\log \left[\frac{1}{K} \sum_{k \in i} H H I_{k t}\right]$ where $H H I_{k}$ is the Herfindahl index for SIC-4 industry $k$ that is part of SIC-2 industry $i$, and $\mathrm{K}$ is the number of SIC-4 industries that constitute the focal SIC-2 industry. $\mathrm{HHI}_{k}$, the Herfindahl index for SIC-4 industry $k$, is for all firms $j$ that constitute industry $k, H H I_{k t}=\sum_{j \in k}\left(\text { Sales }_{j t} / \text { TotalSales }_{k t}\right)^{2}$ for Sales $_{j t}>0$.

$\mathrm{GROWTH}_{\mathrm{t}}$ Average sales growth over last two years in a given SIC-2 industry $i$; i.e, for J firms $j$ that constitute industry $i$, GROWTH $_{i t}=\frac{1}{J} \sum_{j \in i}\left[\left(\right.\right.$ Sales $_{j t}-$ Sales $\left._{j t-2}\right) /$ Sales $\left._{j t-2}\right]$ for Sales $_{j t}$, Sales $_{j t-2}>0$.

$\mathrm{CASH}_{\mathrm{t}}$ Average earnings before interest, taxes, depreciation and amortization (EBITDA) over sales in a given SIC-2 industry; i.e, for $\mathrm{J}$ firms $j$ that constitute industry $i$,

$$
C A S H_{i t}=\frac{1}{J} \sum_{j \in i}\left(\text { EBITDA }_{j t} / \text { Sales }_{i t}\right) \text { for } \text { Sales }_{j t}>0 \text {. }
$$


Table 2. Preliminary Statistics

\begin{tabular}{|c|c|c|c|c|c|}
\hline Variable & Obs. & Mean & Std. Dev. & Min. & Max. \\
\hline Horizontals & 607 & 25.66 & 44.10 & 0 & 342 \\
\hline $\begin{array}{l}\text { Non- } \\
\text { Horizontals }\end{array}$ & 607 & 12.28 & 15.80 & 0 & 173 \\
\hline Total-Mergers & 607 & 37.94 & 55.60 & 0 & 515 \\
\hline $\begin{array}{l}\text { Relative- } \\
\text { Horizontals }\end{array}$ & 607 & 0.54 & 0.28 & 0 & 1 \\
\hline $\begin{array}{l}\text { Investigation- } \\
\text { Rate }\end{array}$ & 607 & 0.08 & 0.14 & 0 & 1 \\
\hline $\begin{array}{l}\text { Challenge- } \\
\text { Rate }\end{array}$ & 607 & 0.1 & 0.32 & 0 & 1 \\
\hline $\begin{array}{l}\text { Prohibition- } \\
\text { Rate }\end{array}$ & 607 & 0.09 & 0.26 & 0 & 1 \\
\hline Court-Win-Rate & 607 & 0.02 & 0.16 & 0 & 1 \\
\hline Court-Loss-Rate & 607 & 0.03 & 0.2 & 0 & 1 \\
\hline $\mathrm{HHI}$ & 607 & 0.21 & 0.14 & 0.02 & 0.89 \\
\hline Growth & 607 & 0.19 & 0.16 & -0.24 & 1.18 \\
\hline Cash & 607 & 0.12 & 0.10 & -0.31 & 0.58 \\
\hline
\end{tabular}


Table 3. Industry-Level Correlations Between Relative Horizontals and Antitrust Actions

\begin{tabular}{|c|c|c|c|c|c|c|c|}
\hline SIC2 & Industry & $\begin{array}{c}\text { Mean } \\
\text { Relative } \\
\text { Horizontals }\end{array}$ & $\begin{array}{c}\text { Correlation of } \\
\text { Relative } \\
\text { Horizontals }_{\mathrm{t}} \\
\text { \& Investigation- } \\
\text { Rate }_{\mathrm{t}-1} \\
\end{array}$ & $\begin{array}{l}\text { Correlation of } \\
\text { Relative Horizontals } \\
\text { \& Challenge-Rate } \\
\text { t-1 }\end{array}$ & $\begin{array}{l}\text { Correlation of } \\
\text { Relative } \\
\text { Horizontals }_{\mathrm{t}} \\
\text { \& Prohibition- } \\
\text { Rate }_{\mathrm{t}-1} \\
\end{array}$ & $\begin{array}{l}\text { Correlation of } \\
\text { Relative } \\
\text { Horizontals }_{\mathrm{t}} \\
\text { \& Court-Win- } \\
\text { Rate }_{\mathrm{t}-1} \\
\end{array}$ & $\begin{array}{l}\text { Correlation of } \\
\text { Relative Horizontals } \\
\text { \& Court-Loss-Rate }{ }_{t-1}\end{array}$ \\
\hline 14 & $\begin{array}{l}\text { Mining And Quarrying of Nonmetallic } \\
\text { Minerals }\end{array}$ & .4585578 & -0.6699 & -0.8345 & 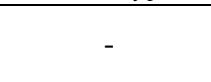 & 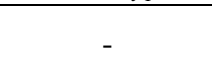 & 0.7498 \\
\hline 20 & Food & .6371733 & -0.6932 & -0.5912 & -0.9134 & -0.4383 & 0.2079 \\
\hline 26 & Paper and Allied Products & .602774 & -0.3942 & -0.0522 & -0.2637 & - & - \\
\hline 27 & Printing, Publishing and Allied Industries & .7843851 & -0.5260 & 0.4544 & 0.1538 & 0.4110 & 0.3019 \\
\hline 28 & Chemicals And Allied Products & 635511 & -0.9308 & -0.7322 & -0.6037 & -0.4928 & - \\
\hline 34 & Fabricated Metal Products & .4926078 & -0.5388 & -0.4468 & -0.8321 & -0.5455 & - \\
\hline 35 & $\begin{array}{l}\text { Industrial \& Commercial Machinery \& } \\
\text { Computer Equipment }\end{array}$ & .5435841 & -0.3723 & -0.8598 & -0.7151 & -0.4443 & -0.7195 \\
\hline 36 & $\begin{array}{l}\text { Electronic and Other Electrical Equipment } \\
\text { and Components }\end{array}$ & .5660684 & -0.6065 & -0.5776 & -0.3088 & - & - \\
\hline 37 & Transportation Equipment & .5382995 & -0.0220 & -0.2245 & 0.2174 & - & - \\
\hline 38 & $\begin{array}{l}\text { Measuring \& Controlling Instruments; } \\
\text { Photographic, Medical \& Optical Goods; } \\
\text { Watches \& Clocks }\end{array}$ & .5498967 & -0.5857 & -0.7109 & -0.8641 & -0.4389 & -0.6246 \\
\hline 45 & Transportation By Air & .6703764 & 0.1485 & -0.1147 & - & - & - \\
\hline 48 & Communications & .7163522 & 0.1348 & 0.8588 & - & - & - \\
\hline 49 & Electric, Gas, and Sanitary Services & .7457425 & -0.5228 & 0.5521 & -0.2519 & - & - \\
\hline 54 & Food Stores & .7056017 & -0.7901 & -0.229 & - & - & - \\
\hline 73 & Business Services & .5389618 & 0.0800 & -0.4651 & -0.1235 & - & - \\
\hline 80 & Health Services & 8686539 & -0.7594 & 0.8257 & -0.4454 & -0.7132 & 0.2932 \\
\hline
\end{tabular}

NOTE.-Reporting no value (i.e., “_“) indicates the lack of non-zero values for the relevant deterrence variable in that particular industry. 
Before engaging in more formal analysis, Table 3 provides some industry-level evidence on the nature of the data and the relationships between the five deterrence variables and relative-horizontal merger activity. The table first reports the means for the 'relativehorizontal' merger variable for sixteen 2-digit SIC industries. ${ }^{13}$ The table also reports correlations between our five deterrence variables (lagged) and the relative number of horizontal mergers. Specifically, the challenge-rate variable indicates a negative correlation with relative-horizontal merger activity in 12 of 16 industries; the investigation-rate indicates a negative correlation with relative-horizontal merger activity in 13 of 16 industries; the prohibition-rate indicates a negative correlation with relative-horizontal merger activity in 10 of the 12 industries which exhibit prohibitions; the court-win-rate indicates a negative correlation with relative-horizontal merger activity in 6 of the 7 industries where antitrust officials win cases in court; and finally, the court-loss-rate indicates a positive correlation - per expectation - with relative-horizontal merger activity in 4 of the 7 industries where antitrust officials lose cases in court. Accordingly, these preliminary tests support the presence of deterrence effects for four merger policy instruments (investigations, challenges, prohibitions, and court-wins) and also support an inverse deterrence effect for court-losses: when antitrust officials lose in court. Yet in order to draw stronger causal inferences, we must move beyond these preliminary tests.

\section{Estimation and Choice of Variables}

\subsection{Composition-Based Effects}

As previously argued, any study of merger behavior should take into account that mergers manifest in wave-like patterns - this is also the case in our sample as it encompasses the merger wave of the late 1990s. Figure 2 illustrates that the cyclical pattern of merger activity is by-and-large driven by horizontal mergers; i.e., merger waves are composed of horizontal - not

\footnotetext{
${ }^{13}$ The sixteen industries are those with at least 3 non-zero observations for our important challenge-rate variable.
} 
non-horizontal - mergers. Thus, our main construct of interest, Relative-Horizontals, shows the beginning of a wave-like pattern.

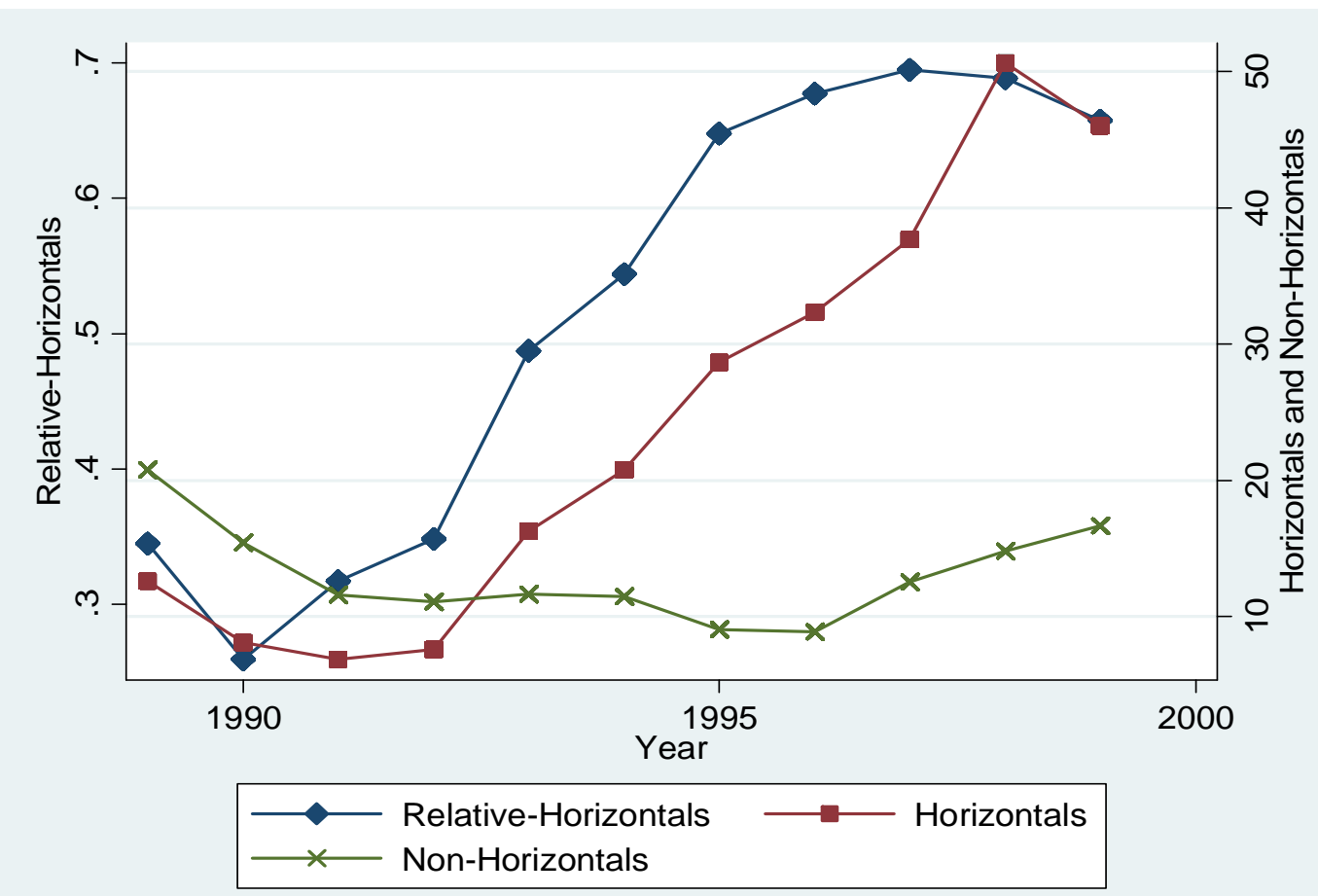

Figure 2. The Average Number of 'Relative-Horizontal', 'Horizontal', and 'NonHorizontal’ Mergers Per Industry (1989-1999)

Accordingly, we include lagged dependent variables as right-hand side regressors; hence, current merger behavior is partly explained by past merger behavior. We also include year dummies to capture additional period-specific shocks. Further, given that merger waves can be partly explained by industry factors, we include relevant measures as indicated by Andrade and Stafford (2004). The Andrade and Stafford set-up is most suited for our purposes, as they consider the factors driving industry-level patterns of merger intensity. In particular, their panel regressions find industry factors - such as concentration, sales growth and cash flow - to drive merger activity. ${ }^{14}$ Accordingly, we construct annual two-digit level measures for HHI ('HHI’), sales growth ('Growth’) and cash flow ('Cash’). In our empirical specification,

\footnotetext{
${ }^{14}$ See Andrade and Stafford (2004), Table 3 (b) and (c) on page 12-13, where the 'industry adjusted' regressions are fixed effects estimations for panel data.
} 
we lag these measures by one year for two reasons. First, due to the matching of different datasets and slightly different year bases (fiscal year versus calendar year), it is the easiest means to ensure that the control variables precede the dependent variable. Second and related, it is a first step in correcting for the potential endogeneity of the control variables; for example, industry concentration may go up due to increased (horizontal) merger activity.

Summarizing the above, we estimate how the ratio of horizontal over total mergers Relative-Horizontals - depends on past merger ratios (i.e., two lags of the dependent variable), ${ }^{15}$ the five conditional probabilities, and merger-wave controls:

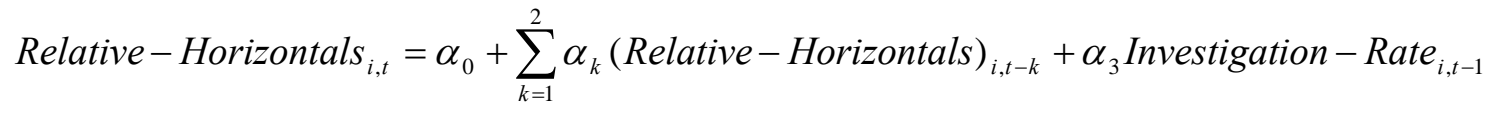

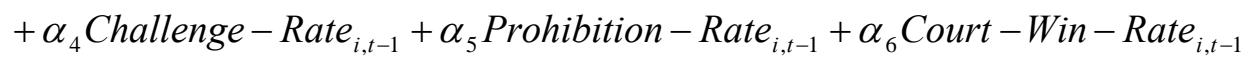

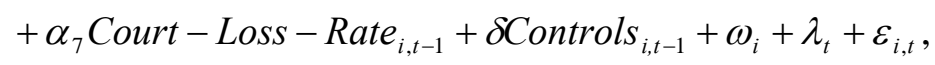

where $i$ indexes the two-digit SIC industries, $t$ indexes time (year), and $k$ allows for convenient expressions. The merger policy actions consist of two-year averages of the conditional probabilities of Investigation, Challenge and Prohibition - all lagged. The two court procedure variables - Court-Win-Rate and Court-Loss-Rate - respectively capture the sum of court-wins and court-losses over two years $(\mathrm{t}+\mathrm{t}-1)$ divided by the twice-lagged sum of prohibitions over two years $(\mathrm{t}-1+\mathrm{t}-2) .{ }^{16}$ Controls represents the vector of lagged merger-wave control variables: industry concentration (HHI), sales growth (Growth) and cash flow (Cash). Finally, $\omega_{i}$ represents the unobserved industry-specific effect, $\lambda_{t}$ the year dummies and $\varepsilon_{i, t}$ the disturbances.

\footnotetext{
${ }^{15}$ Regressions indicate that the model with two lagged dependent variables yields the best results in terms of ameliorating serial correlation.

${ }^{16}$ This lagging of the denominator twice more than the numerator follows from the crime-and-punishment literature where they key on the fact that death sentences take 7 years on average to be commuted, hence the conditional probability of eliciting an execution is the number of capital punishments carried out in year $t$ divided by the number of death sentences in year t-7 (see for example Dezhbakhsh et al. 2003). In our case, a contested prohibition takes two years on average to wind its way through the courts; hence, the $t$ and $t-1$ measures for the numerator (court-wins or court-losses), and the t-2 and t-3 measures for the denominator (prohibitions).
} 


\subsection{Frequency-Based Effects}

After analyzing the effects of the deterrence variables on the composition of proposed mergers, we can trace back how merger policy instruments potentially affect specific types of M\&A behavior. In other words, if merger policy instruments have a deterrence effect on the composition of proposed mergers, it is possible that this composition-based effect owes to firms proposing fewer horizontal mergers and/or more non-horizontal mergers. As already noted, it is important to ensure that it is the deterrence of horizontals - and not the encouragement of non-horizontals - that resides behind any manifested deterrence effects. Therefore, in a second step, we consider whether merger policy instruments have an impact on horizontal and non-horizontal mergers separately. In other words, we estimate the following two specifications:

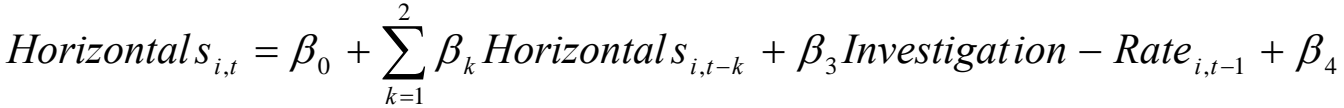

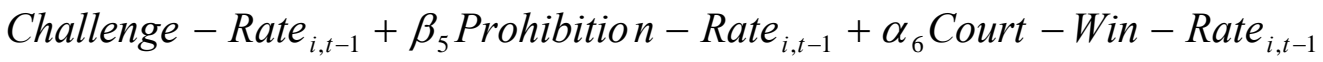

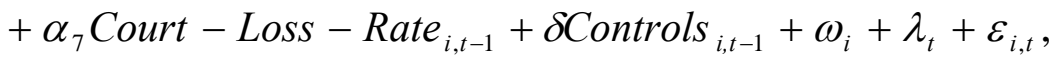

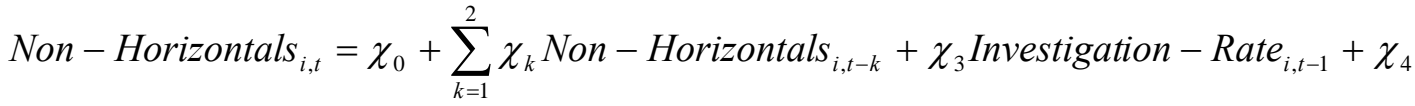

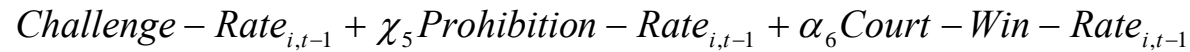

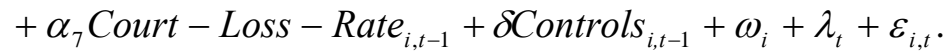

Donohue and Wolfers (2005) point out that measuring deterrence requires the consideration of scaling issues; hence, we log-transform our merger frequency variables (Horizontal and NonHorizontal) to yield some additional estimation advantages. ${ }^{17}$ First, log-transforming helps moderate - or cancel out - potential size differences between the different industries via the estimation of a log-linear regression model (recall that our conditional probabilities are not in logs). Second, log-transforming also addresses to some extent the count nature of the data on merger frequencies by making the variable constructs more continuous.

\footnotetext{
${ }^{17}$ We include lags of non-horizontal mergers as explanatory variables for reasons beyond simple consistency with the previous regression specifications. Tests show that, although non-horizontal mergers do not move in waves (see Figure 2), the number of non-horizontal mergers still correlate over time.
} 


\subsection{Estimation Strategy}

For all three specifications, we employ the methodology of dynamic panel data models (see Bond 2002 for an overview), as we include autoregressive dynamics of the dependent variable (Relative-Horizontals, Horizontals or Non-Horizontals) on the right-hand side. The strong potential for correlation between the lagged dependent variable(s) and error terms implies that a least-squares or within-groups estimation would result in biased and inconsistent estimates. Hence, we estimate our expression instrumenting for our lagged dependent variables using the System GMM estimator proposed by Arellano and Bover (1995). Dynamic panel data methods are specially designed to properly control for wave-contexts: Bond $(2002,142)$ states that “allowing for dynamics in the underlying process [a merger wave] may be crucial for recovering consistent estimates of other parameters [the deterrence variables]”. Given that the crime-and-punishment and merger-wave literatures have not used this methodology, employing the appropriate dynamic panel method represents a merit of this contribution.

Arellano and Bond (1991) developed a GMM estimator that treats the model as a system of equations - one for each time period - where the predetermined and endogenous variables in first differences are instrumented with suitable lags of their own levels. A problem with the original Arellano-Bond estimator is that lagged levels are often poor instruments for first differences. Adding an equation in levels to be estimated with the equation in first differences (namely, estimating a system of equations) improves the performance of the estimator. Arellano and Bover (1995) described how - by adding the original equations in levels - additional moment conditions could be brought to bear to increase efficiency and reduce finite sample bias.

It behooves us then to employ Stata’s procedure for System GMM in order to instrument for all potentially endogenous and predetermined variables. First, we treat the lagged dependent variables as endogenous (as the methodology of dynamic panel data prescribes). Second, recall that lagging the deterrence variables mitigates simultaneity-based endogeneity problems: the 
investigation-rate directly through its denominator containing horizontal mergers; and the investigation, challenge, prohibition, court-win and court-loss rates indirectly through these merger policy actions possibly being a subset of the number of notified mergers in a year. Yet, our lagged deterrence variables may be correlated with past merger notification shocks when an antitrust authority does not come to a decision in the same year as the merger notification. Third, despite the lagging of our wave variables, they may still be predetermined as merger shocks can, for example, propagate slowly to sales and profits.

Accordingly, we use System GMM to instrument for the clearly endogenous lagged dependent variables, the potentially endogenous deterrence variables, and the potentially predetermined merger-wave variables. Two testable assumptions are required for the appropriateness and validity of these instruments in GMM estimation. First, in order to reach identification, the disturbances $\varepsilon_{i, t}$ must be serially uncorrelated. This is equivalent to having no second-order serial correlation in the first-differenced residuals, and can thus be directly tested in the first-differenced model. Second, the instruments must be uncorrelated with the firstdifferenced residuals, which can be tested using the Sargan test of over-identifying restrictions.

Beyond the standard use of all available information regarding absolute and firstdifferenced lagged values with System GMM, we are able to introduce additional exogenous constructs in order to augment our matrix of instruments. In particular, the industry deregulation shocks from Harford (2005), the three Presidential administrations (Reagan, BushI, and Clinton), an estimate of the antitrust staff devoted to that industry in previous years ${ }^{18}$, year-dummies and a time-trend are all introduced as additional instruments. While employing the later two constructs as instruments is standard reasoning, the other additional instruments require a bit of explanation as to why we consider them to be valid instruments. First, industry

\footnotetext{
${ }^{18}$ Industry deregulation shocks and the estimate of antitrust staff devoted to that industry in previous years are both constructs that vary over industries and years, while the other additional 'exogenous constructs' simply vary over years. Total U.S. antitrust staffing data derive from Kwoka (1999) and were given appropriate industry weights by the number of previous antitrust investigations in the particular two-digit industry. Hence, this construct approximates the relative number of staff (human-resources) previously dedicated to each particular industry sector.
} 
deregulation can be considered to be exogenously applied by regulatory authorities; thus, deregulation may only indirectly influence merger activity via its influence on merger policy actions. For instance, Carlton and Picker (2006, 22) suggest the interconnection between regulation and antitrust policy when they state that "Recent history highlights a move away from regulation towards antitrust as a means to control competition and reveals how regulation and antitrust can be both substitutes and, in some settings, complements”. Second, Presidential administrations have traditionally had a significant influence on the tenor of antitrust policy; further, firms find it difficult to anticipate such changes to merger policy - i.e., they represent politically-driven exogenous shocks to merger policy. ${ }^{19}$ Third, previous levels of human resources dedicated by U.S. antitrust authorities to particular industries should be an additional - and more precise - indicator of the importance (and familiarity) administrators give to merger policy in a given industrial sector. ${ }^{20}$

A downside of the proposed GMM methodology is that - although the number of valid moment conditions increases with the number of periods and these improve efficiency - the system GMM estimator can use too many moment conditions with respect to the number of available observations. Put simply, too many instruments may lead to over-fitting the

\footnotetext{
${ }^{19}$ For example, significant differences in our deterrence variables manifest when you consider variation across the Presidential administrations (Reagan, Bush-I, and Clinton) in our sample. This variation suggests that the conditional probabilities are exogenously determined by shocks from Presidential politics. Consider further the statements in a recent Washington Post article ('U.S. Clears the Way for Antitrust Crackdown: Justice Dept. to Reverse Looser Policy of Bush Administration’ by Cecilia King; May12, 2009; http://www.washingtonpost.com/wpdyn/content/article/2009/05/11/AR2009051101189.html?referrer=emailarticle ): “The Obama administration signaled yesterday that it would take an aggressive stand against companies that engage in anti-competitive behavior, reversing looser policies of the past eight years that critics called friendly toward big firms"; and "During the Bush administration, nearly every high-tech and telecommunications merger before the antitrust division at the Justice Department was approved”.

${ }^{20}$ We find support for this reasoning when conducting some simple diagnostics. First, we estimate some 'firststage' fixed-effects panel regressions and find support for a relationship between the additional instruments and the deterrence variables: deregulation shocks significantly impact challenge-rate; Presidential administrations significantly impact prohibition-rate, and antitrust staffing by industry significantly impacts both the investigation and challenge rates. Second, we also find evidence that these instruments improve the orthogonality conditions between the independent variables and the error terms. Using the GMM methodology on our standard regression specifications (relative-horizontals, horizontals and non-horizontals), we compare the Sargan tests for regression equations with and without the additional instruments. For all three specifications, the Sargan tests improve with the additional instruments; thus, indicating that these additional instruments do indeed influence merger activity only indirectly via the deterrence variables. Hence, we are confident that including these additional instruments adds value to our matrix of instruments. Though it is important to underscore that the results do not substantially change when we simply employ the GMM estimation technique without additional instruments.
} 
instrumented variables and bias results when GMM is employed on all of the right-hand-side variables. Thus, as a robustness check, we estimate our regression equation while treating the merger-wave variables as exogenous and instrumenting only for the lagged dependent and deterrence variables. By doing so, we can keep the number of instruments relatively low and mitigate the over-fitting bias. Still, it could be that the efficiency gains from system GMM are relatively small. Therefore - keeping in mind that fixed-effects estimations potentially suffer from correlation between the (transformed) lagged dependent variables and the (transformed) error term - we also report fixed effects results with standard errors clustered at the industry level. Clustering the standard errors mitigates to some extent remaining serial correlation in the merger series, and has the added advantage that it is the currently preferred practice in the crime-and-punishment deterrence literature. Although invoking GMM seems better suited to deal with a wave-like phenomenon such as mergers, the fixed effects estimation serves as a robustness check and allows us to make the link with the bulk of the deterrence literature. Finally, as an additional robustness check, we also employ Tobit fixed effects panel data estimation. ${ }^{21}$ Given that we deal with the annual number of horizontal mergers in a particular two-digit industry, it is possible that our dependent variable shows a truncated distribution, i.e. our merger variable may be left-censored at zero. Although only about $10 \%$ of the observations of our dependent variable are actually zero, we nevertheless report results for the Tobit panel estimation. This estimation also has the added advantage that it can be more directly compared to Andrade and Stafford's (2004) contribution: where they report a Tobit panel estimation for horizontal mergers that we can build upon by including deterrence variables in addition to their industry drivers of merger waves. ${ }^{22}$

\footnotetext{
${ }^{21}$ To be exact, we use an unconditional fixed-effects Tobit model with clustered standard errors. As with the normal fixed effects estimator in our model, it must be kept in mind that unconditional fixed-effects coefficient estimates may be biased due to the untreated endogeneity in the lagged dependent variables. In theory, these models may further yield biased estimates due to the incidental parameter problem, but Greene (2004a, 2004b) shows that this is not the case in practice for panels longer than five periods, as is ours.

${ }^{22}$ Their industries include more 'zero' observations as they employ a different industry definition.
} 
Our main empirical results for each of our three empirical set-ups - the ratio of horizontal to total mergers (specification 1), the number of horizontal mergers (specification 2) and the number of non-horizontal mergers (specification 3) - consist of four regressions that attempt to take the above issues into account. To be exact, each specification involves four regression estimations that all involve fixed period-specific effects to deal with common time-trends, robust variance matrix estimators to deal with potential heteroskedasticity, and clustered standard errors on the panel when the GMM procedure is not invoked. Regression \#1 reports the results of the fixed effects procedure. Regression \#2 reports the results of the Tobit fixed effects procedure. Regression \#3 reports the results where only the autoregressive and deterrence variables are instrumented for with System GMM. Regression \#4 reports the results where - in addition to the autoregressive and deterrence variables - the merger-wave variables are also instrumented for with System GMM.

\section{Empirical Results}

Table 4 reports the estimation results for the four regressions in the first specification: where the composition of merger activity (Relative-Horizontals) is the dependent variable. Before discussing the constructs of primary interest, we comment on the adequateness of the model. First, the Sargan test of over-identifying restrictions yields evidence in both GMM estimations (regressions’ \#3 \& \#4) that one cannot reject the hypothesis of no correlation between instruments and error terms. Second, the null hypothesis of no second order autocorrelation on the error differences also cannot be rejected, suggesting that serial correlation does not exist in error levels (the smallest of both estimations reports $\operatorname{Pr}>\mathrm{z}=0.67$ ). Third, the R-squared term in Regression \#1 is 0.39 . Accordingly, the regression model passes the necessary diagnostics and appears to be well-specified. We comment now on the control variables.

The two lagged dependent variables for Relative-Horizontals seem to be relevant. The first lagged dependent variable is positive and highly significant in all four estimations. The 
second lagged dependent variable is positive - although only significant for the two GMM estimations - yet its inclusion is appropriate as the test for serial correlation in the error term performs better when including the second lag. ${ }^{23}$

The three merger-wave control variables derive from - and generally conform to Andrade and Stafford's (2004) empirical work on merger waves. The HHI variable yields a consistently-significant negative coefficient estimate, thus more concentrated industries tend to have relatively fewer horizontal mergers - in line with the idea that more concentrated industries are more closely scrutinized by the DOJ and FTC. Akin to Andrade and Stafford, the Growth variable yields mostly positive - though insignificant - coefficient estimates; hence, increased sales in an industry appear to be positively associated with higher propensities to engage in horizontal merger activity—a result in line with both prior empirical evidence and theoretical predictions (see Banal-Estanol et al. 2011, for an overview). The Cash variable, however, yields mixed results concerning sign and is moreover never significant.

We can now look at the results for the variables of primary interest: the relationship between the deterrence variables and the composition of future M\&A activity. First, the probability that a proposed merger is investigated (Investigation-Rate) has a statistically significant and negative impact on the ratio of future horizontal mergers in one of the four regression equations. Second, the conditional probability of applying an antitrust action once investigated (Challenge-Rate) has a statistically significant and negative impact on the ratio of future horizontal mergers in all four regression equations. Third, the conditional probability of applying prohibitions (Prohibition-Rate) is insignificant in all four regression equations. Fourth, the conditional probability of antitrust winning a court-case (court-win-rate) is insignificant in all four regression equations. Fifth, the conditional probability of antitrust losing a court-case (court-loss-rate) is positive but insignificant in all four regression equations.

\footnotetext{
${ }^{23}$ While including (more) lagged terms of the dependent variable directly helps in modeling the underlying autoregressive process of mergers, this does not per se solve the potential autocorrelation problem. Keele and Kelly (2006) note that lagged dependent variables are often found to improve the autocorrelation issue in practice- the case in our specification as well.
} 
The strong and consistent impact of the Challenge variable suggests that spikes in the relative use of antitrust actions send a clear signal of toughness by antitrust authorities that is internalized by firms, as it significantly reduces the relative number of horizontal mergers in subsequent years. For instance, if one were to take the coefficient estimate for challenge-rate from regression $4(-0.133)$ and consider the impact of a one-standard deviation increase in the challenge-rate (while benchmarking the number of horizontal and non-horizontal mergers at their respective sample means of 25.66 and 12.28); then, horizontal merger activity per sector would drop by a little over four mergers (from 25.66 to 21.40) on average due to the increased challenge-rate. ${ }^{24}$ Or put in terms of relative horizontal mergers, horizontal transactions would go from $67.6 \%$ to $63.5 \%$ of the merger activity in a sector.

\footnotetext{
${ }^{24}$ The differences in the results for challenge-rate across the four different regressions is driven by instrumentation; in particular, Regressions' 1 \& 2 do not instrument, while Regressions' 3 \& 4 do instrument for Challenge-Rate. Accordingly, Regressions’ 3 \& 4 exhibit wider standard errors, but larger coefficient estimates after correcting for endogeneity.
} 
Table 4. Panel Data Estimations (Dependent Variable: Relative-Horizontals)

\begin{tabular}{|c|c|c|c|c|}
\hline Variable & $\begin{array}{l}\text { Fixed- } \\
\text { Effects }\end{array}$ & $\begin{array}{c}\text { Tobit } \\
\text { Fixed-Effects } \\
\text { (2) }\end{array}$ & $\begin{array}{c}\text { Instrumenting } \\
\text { with GMM for } \\
\text { Autoregressive \& } \\
\text { Deterrence Variables } \\
\text { (3) }\end{array}$ & $\begin{array}{l}\text { Instrumenting } \\
\text { with GMM for } \\
\text { Full-Set of } \\
\text { Variables } \\
\text { (4) }\end{array}$ \\
\hline \multirow[t]{2}{*}{ Relative-Horizontals $\mathrm{t}-1$} & $0.154 * * *$ & $0.152 * * *$ & $0.267 * * *$ & $0.255^{* * *}$ \\
\hline & $(0.0484)$ & $(0.0524)$ & $(0.0776)$ & $(0.0708)$ \\
\hline \multirow[t]{2}{*}{ Relative-Horizontals $\mathrm{t}_{\mathrm{t}-2}$} & 0.0561 & 0.0512 & $0.223 * *$ & $0.216^{* * *}$ \\
\hline & $(0.0685)$ & $(0.0770)$ & $(0.0978)$ & $(0.0654)$ \\
\hline \multirow[t]{2}{*}{ Investigation-Rate $_{\mathrm{t}-1}$} & $-0.106 *$ & -0.111 & -0.00670 & -0.142 \\
\hline & $(0.0638)$ & $(0.0676)$ & $(0.166)$ & $(0.172)$ \\
\hline \multirow[t]{2}{*}{ Challenge-Rate ${ }_{\mathrm{t}-1}$} & $-0.0614 * * *$ & $-0.0642 * * *$ & $-0.0740 * *$ & $-0.133 * *$ \\
\hline & $(0.0213)$ & $(0.0222)$ & $(0.0370)$ & $(0.0624)$ \\
\hline \multirow[t]{2}{*}{ Prohibition-Rate $\mathrm{t}-1$} & -0.0223 & -0.0241 & 0.0481 & 0.119 \\
\hline & $(0.0344)$ & $(0.0390)$ & $(0.0742)$ & $(0.0806)$ \\
\hline \multirow[t]{2}{*}{ Court-Win-Rate $\mathrm{t}-1$} & -0.0198 & -0.0140 & 0.0330 & 0.0232 \\
\hline & $(0.0448)$ & $(0.0456)$ & $(0.140)$ & $(0.109)$ \\
\hline \multirow[t]{2}{*}{ Court-Loss-Rate ${ }_{t-1}$} & 0.0176 & 0.0156 & 0.0962 & 0.0827 \\
\hline & $(0.0261)$ & $(0.0237)$ & $(0.167)$ & $(0.104)$ \\
\hline \multirow[t]{2}{*}{ Cash $_{\mathrm{t}-1}$} & -0.0250 & -0.0314 & 0.193 & -0.00448 \\
\hline & $(0.272)$ & $(0.366)$ & $(0.468)$ & $(0.229)$ \\
\hline \multirow[t]{2}{*}{ Growth $_{\mathrm{t}-1}$} & 0.0575 & 0.0645 & 0.265 & -0.0310 \\
\hline & $(0.0838)$ & $(0.0899)$ & $(0.249)$ & $(0.175)$ \\
\hline \multirow[t]{2}{*}{$\mathrm{HHI}_{\mathrm{t}-1}$} & $-0.174 * * *$ & $-0.207 * * *$ & $-0.122 * *$ & $-0.0964 * *$ \\
\hline & $(0.0481)$ & $(0.0590)$ & $(0.0505)$ & $(0.0451)$ \\
\hline \multirow[t]{2}{*}{ Constant } & 0.128 & -0.0741 & -0.0315 & 0.118 \\
\hline & $(0.0972)$ & $(0.0936)$ & (0.0778) & (0.0807) \\
\hline \multicolumn{2}{|l|}{$\begin{array}{l}\text { Arellano-Bond test that aver. auto } \\
\text { covariance in residuals of order } 2 \text { is } 0\end{array}$} & \multirow[b]{3}{*}{$\begin{array}{r}0.205^{* * *} \\
(0.0153)\end{array}$} & $\begin{array}{c}\mathrm{z}=-.35776 \\
\operatorname{Pr}>\mathrm{z}=0.7205\end{array}$ & $\begin{array}{c}z=-.42191 \\
\operatorname{Pr}>z=0.6731\end{array}$ \\
\hline $\begin{array}{l}\text { Sargan Test of over-identifying } \\
\text { restrictions }\end{array}$ & & & $\begin{array}{l}\text { chi2 }(95)=73.599 \\
\text { Prob }>\text { chi } 2=0.949\end{array}$ & $\begin{array}{l}\operatorname{chi} 2(116)=122.470 \\
\text { Prob }>\text { chi2 }=0.322\end{array}$ \\
\hline $\begin{array}{l}\text { Sigma } \\
\text { Constant }\end{array}$ & & & & \\
\hline $\mathrm{R}^{2}$ & 0.39 & & & \\
\hline \multicolumn{5}{|c|}{$\begin{array}{l}\text { NOTE.-The dependent variable is the relative number of horizontal over total notified mergers. All four estimations involve } \\
\text { fixed period-specific effects (year dummies) and } 607 \text { observations. The standard errors are in brackets and are robust } \\
\text { throughout, while Regressions’ } 1 \& 2 \text { also involve clustering on the panel. Furthermore, } * * *=1 \% \text {, } * *=5 \% \text {, and } *=10 \% \\
\text { Significance. }\end{array}$} \\
\hline
\end{tabular}


A short review of the non-significant findings is also in order. First, the probability of eliciting investigations yields a negative impact on the proclivity of firms to engage in future horizontal mergers, yet this impact is far less robust (significant only in Regression 1 -the fixed effects specification) than the Challenge-Rate variable. It is also worth noting that the use of more severe antitrust actions - i.e., employing more prohibitions with respect to remedies does not appear to involve robust deterrence in that prohibitions do not appear to yield significantly more deterrence than do remedies (i.e., challenges in general). Lastly, the acrossthe-board insignificance of court-win-rate and court-loss-rate suggest that court decisions do not yield substantial impact on future relative-horizontal merger activity. With regard to the insignificance of the prohibition-rate, court-win-rate and court-loss-rate, it should be noted that prohibitions and court-cases are much rarer events as compared to investigations and remedies, thus the insignificance of these variables may be due to the lack of sufficient observations.

In order to ensure that the deterrence effects elicited above are reflective of reduced horizontal merger activity and not increased non-horizontal merger activity (since both changes could be behind relatively fewer horizontal mergers), we investigate the underlying merger patterns to respectively consider the impact of the deterrence variables on the absolute number of horizontal and non-horizontal mergers. In other words, we now attempt to factor the underlying frequency-based deterrence effects in order to ensure that we are correctly interpreting composition-based deterrence effects. We do so simply by employing the same specification as before with the exception of respectively replacing relative-horizontals with the number of horizontal (Table 5) and non-horizontal (Table 6) mergers. 
Table 5. Panel Data Estimations (Dependent Variable: Horizontals)

\begin{tabular}{|c|c|c|c|c|}
\hline Variable & $\begin{array}{l}\text { Fixed- } \\
\text { Effects }\end{array}$ & $\begin{array}{c}\text { Tobit } \\
\text { Fixed-Effects }\end{array}$ & $\begin{array}{l}\text { Instrumenting } \\
\text { with GMM for } \\
\text { Autoregressive \& } \\
\text { Deterrence Variables } \\
\quad \text { (3) }\end{array}$ & $\begin{array}{l}\text { Instrumenting } \\
\text { with GMM for } \\
\text { Full-Set of } \\
\text { Variables } \\
\quad(4)\end{array}$ \\
\hline \multirow{2}{*}{ Horizontals $_{\mathrm{t}-1}$} & $0.444 * * *$ & $0.436 * * *$ & $0.499 * * *$ & $0.595^{* * *}$ \\
\hline & $(0.0518)$ & $(0.0541)$ & $(0.0778)$ & $(0.0595)$ \\
\hline \multirow[t]{2}{*}{ Horizontals $\mathrm{t}-2$} & $0.132 * * *$ & $0.125^{* *}$ & $0.240 * * *$ & $0.274 * * *$ \\
\hline & $(0.0435)$ & $(0.0493)$ & $(0.0737)$ & $(0.0572)$ \\
\hline \multirow[t]{2}{*}{ Investigation-Rate $_{\mathrm{t}-1}$} & -0.183 & -0.200 & -0.201 & -0.442 \\
\hline & $(0.166)$ & $(0.182)$ & $(0.395)$ & $(0.588)$ \\
\hline \multirow[t]{2}{*}{ Challenge-Rate $_{\mathrm{t}-1}$} & $-0.205 * * *$ & $-0.215^{* * *}$ & $-0.243^{* * *}$ & $-0.359 * *$ \\
\hline & $(0.0544)$ & $(0.0620)$ & $(0.0924)$ & $(0.161)$ \\
\hline \multirow[t]{2}{*}{ Prohibition-Rate $_{\mathrm{t}-1}$} & -0.0479 & -0.0550 & 0.262 & 0.391 \\
\hline & $(0.0881)$ & $(0.0990)$ & $(0.211)$ & $(0.314)$ \\
\hline \multirow[t]{2}{*}{ Court-Win-Rate $_{\mathrm{t}-1}$} & -0.103 & -0.0847 & 0.00340 & -0.142 \\
\hline & $(0.191)$ & $(0.193)$ & $(0.274)$ & $(0.552)$ \\
\hline \multirow[t]{2}{*}{ Court-Loss-Rate $\mathrm{t}_{\mathrm{t}-1}$} & 0.116 & 0.108 & $0.399 *$ & $0.634^{*}$ \\
\hline & $(0.0697)$ & $(0.0710)$ & $(0.239)$ & $(0.367)$ \\
\hline \multirow[t]{2}{*}{ Cash $_{\mathrm{t}-1}$} & -0.136 & -0.0887 & -5.758 & 0.844 \\
\hline & $(0.339)$ & $(0.584)$ & (4.545) & (1.563) \\
\hline \multirow[t]{2}{*}{ Growth $_{\mathrm{t}-1}$} & $0.435^{* *}$ & $0.479 * *$ & -0.682 & -0.442 \\
\hline & $(0.198)$ & $(0.225)$ & $(0.752)$ & $(0.666)$ \\
\hline \multirow[t]{2}{*}{$\mathrm{HHI}_{\mathrm{t}-1}$} & $-0.457 * * *$ & $-0.557 * * *$ & $-1.117 * *$ & $-0.371 * * *$ \\
\hline & $(0.153)$ & $(0.168)$ & $(0.566)$ & $(0.113)$ \\
\hline \multirow[t]{2}{*}{ Constant } & 0.211 & & -0.192 & -0.112 \\
\hline & $(0.296)$ & & $(0.525)$ & $(0.227)$ \\
\hline \multicolumn{2}{|l|}{$\begin{array}{l}\text { Arellano-Bond test that aver. auto } \\
\text { covariance in residuals of order } 2 \text { is } 0\end{array}$} & & $\begin{array}{c}\mathrm{z}=-.95143 \\
\operatorname{Pr}>\mathrm{z}=0.3414\end{array}$ & $\begin{array}{c}\mathrm{z}=-.60851 \\
\operatorname{Pr}>\mathrm{z}=0.5428\end{array}$ \\
\hline $\begin{array}{l}\text { Sargan Test of over-identifying } \\
\text { restrictions }\end{array}$ & & & $\begin{array}{l}\text { chi2 } 2(107)=76.936 \\
\text { Prob }>\text { chi2 }=0.9875\end{array}$ & $\begin{array}{l}\text { chi2 }(136)=119.897 \\
\text { Prob }>\text { chi2 }=0.835\end{array}$ \\
\hline \multicolumn{2}{|l|}{$\begin{array}{l}\text { Sigma } \\
\text { Constant }\end{array}$} & $\begin{array}{l}0.543 * * * \\
(0.0285)\end{array}$ & & \\
\hline $\mathrm{R}^{2}$ & 0.74 & & & \\
\hline \multicolumn{5}{|c|}{$\begin{array}{l}\text { NOTE.-The dependent variable is the relative number of horizontal over total notified mergers. All four estimations involve } \\
\text { fixed period-specific effects (year dummies) and } 607 \text { observations. The standard errors are in brackets and are robust } \\
\text { throughout, while Regressions' } 1 \& 2 \text { also involve clustering on the panel. Furthermore, } * * *=1 \% \text {, } * *=5 \% \text {, and } *=10 \% \\
\text { Significance. }\end{array}$} \\
\hline
\end{tabular}


Table 6. Panel Data Estimations (Dependent Variable: Non-Horizontals)

\begin{tabular}{|c|c|c|c|c|}
\hline Variable & $\begin{array}{l}\text { Fixed- } \\
\text { Effects }\end{array}$ & $\begin{array}{c}\text { Tobit } \\
\text { Fixed-Effects } \\
\text { (2) }\end{array}$ & $\begin{array}{c}\text { Instrumenting } \\
\text { with GMM for } \\
\text { Autoregressive \& } \\
\text { Deterrence Variables } \\
\text { (3) }\end{array}$ & $\begin{array}{l}\text { Instrumenting } \\
\text { with GMM for } \\
\text { Full-Set of } \\
\text { Variables } \\
\text { (4) }\end{array}$ \\
\hline \multirow[t]{2}{*}{ Non-Horizontals ${ }_{\mathrm{t}-1}$} & $0.127 * *$ & $0.120 * *$ & $0.387 * * *$ & $0.361 * * *$ \\
\hline & $(0.0573)$ & $(0.0599)$ & $(0.0679)$ & $(0.0990)$ \\
\hline \multirow[t]{2}{*}{ Non-Horizontals $\mathrm{t}-2^{2}$} & $0.201^{* * *}$ & $0.205^{* * *}$ & $0.395^{* * *}$ & $0.330 * * *$ \\
\hline & $(0.0517)$ & $(0.0532)$ & $(0.0649)$ & $(0.0688)$ \\
\hline \multirow[t]{2}{*}{ Investigation-Rate $_{\mathrm{t}-1}$} & -0.0557 & -0.0650 & -0.150 & -0.318 \\
\hline & $(0.213)$ & $(0.215)$ & $(0.429)$ & $(0.408)$ \\
\hline \multirow[t]{2}{*}{ Challenge-Rate ${ }_{\mathrm{t}-1}$} & -0.0322 & -0.0397 & 0.0134 & -0.0687 \\
\hline & $(0.0736)$ & $(0.0770)$ & $(0.375)$ & $(0.315)$ \\
\hline \multirow[t]{2}{*}{ Prohibition-Rate $\mathrm{t}-1$} & -0.0132 & -0.0162 & 0.178 & 0.294 \\
\hline & $(0.0822)$ & $(0.0828)$ & $(0.346)$ & $(0.270)$ \\
\hline \multirow[t]{2}{*}{ Court-Win-Rate $\mathrm{t}-1$} & 0.0137 & 0.0156 & -0.122 & -0.217 \\
\hline & $(0.118)$ & $(0.117)$ & $(0.370)$ & $(0.383)$ \\
\hline \multirow[t]{2}{*}{ Court-Loss-Rate ${ }_{t-1}$} & 0.00515 & 0.00869 & 0.149 & 0.209 \\
\hline & $(0.0913)$ & $(0.0932)$ & $(0.222)$ & $(0.322)$ \\
\hline \multirow[t]{2}{*}{ Cash $_{\mathrm{t}-1}$} & -0.00368 & -0.0560 & -0.883 & -1.251 \\
\hline & $(0.352)$ & $0.430^{*}$ & (1.963) & (1.044) \\
\hline \multirow[t]{2}{*}{ Growth $_{\mathrm{t}-1}$} & $0.423^{*}$ & $(0.243)$ & $1.157^{* * *}$ & 0.563 \\
\hline & $(0.222)$ & 0.00737 & $(0.436)$ & $(0.481)$ \\
\hline \multirow[t]{2}{*}{$\mathrm{HHI}_{\mathrm{t}-1}$} & 0.0134 & $(0.102)$ & -0.0457 & -0.388 \\
\hline & $(0.0934)$ & $(0.102)$ & $(0.191)$ & $(0.239)$ \\
\hline \multirow[t]{2}{*}{ Constant } & $1.300 * * *$ & $0.533 * * *$ & 0.160 & -0.0581 \\
\hline & $(0.249)$ & $(0.0197)$ & $(0.439)$ & $(0.394)$ \\
\hline \multicolumn{2}{|l|}{$\begin{array}{l}\text { Arellano-Bond test that aver. auto } \\
\text { covariance in residuals of order } 2 \text { is } 0\end{array}$} & & $\begin{array}{c}\mathrm{z}=-.12978 \\
\operatorname{Pr}>\mathrm{z}=0.8967\end{array}$ & $\begin{array}{c}\mathrm{z}=.46017 \\
\operatorname{Pr}>\mathrm{z}=0.6454\end{array}$ \\
\hline $\begin{array}{l}\text { Sargan Test of over-identifying } \\
\text { restrictions }\end{array}$ & & & \multirow[t]{3}{*}{$\begin{array}{l}\text { chi2 }(136)=140.515 \\
\text { Prob }>\text { chi2 }=0.3778\end{array}$} & $\begin{array}{r}\text { chi2 }(153)=156.419 \\
\text { Prob }>\text { chi } 2=0.4082\end{array}$ \\
\hline $\begin{array}{l}\text { Sigma } \\
\text { Constant }\end{array}$ & & $\begin{array}{l}0.446 * * * \\
(0.0197)\end{array}$ & & \\
\hline $\mathrm{R}^{2}$ & 0.69 & & & \\
\hline \multicolumn{5}{|c|}{$\begin{array}{l}\text { NOTE.-The dependent variable is the relative number of horizontal over total notified mergers. All four estimations involve } \\
\text { fixed period-specific effects (year dummies) and } 607 \text { observations. The standard errors are in brackets and are robust } \\
\text { throughout, while Regressions' } 1 \& 2 \text { also involve clustering on the panel. Furthermore, } * * *=1 \% \text {, ** }=5 \% \text {, and } *=10 \% \\
\text { Significance. }\end{array}$} \\
\hline
\end{tabular}


Both the horizontal and non-horizontal models seem to be well specified, and the two lagged dependent variables are again empirically relevant. ${ }^{25}$ In terms of control variables in the 'horizontal' mergers specification, the merger-wave variables of Growth (positive) and HHI (negative) generally indicate more robust coefficient estimates as compared to our main estimations on relative-horizontals. In the 'non-horizontal' mergers specification, the mergerwave variables are generally insignificant: with the exception of Growth in two regressions (\#1 \& \#3) and Cash in one regression (\#2). Hence, the merger-wave drivers do not appear to significantly impact non-horizontal merger activity—a result conforming to recent mergerwave papers which have shown that (i) waves are composed of horizontal mergers - see also our Figure 2 - and (ii) industry variables are important in explaining these waves.

We can now consider the results for our primary variables of interest: the five deterrence variables. First, the coefficient estimates for Investigation-Rate are insignificant for all of the regression equations concerning the absolute number of horizontal and non-horizontal mergers. While the insignificant results for non-horizontal mergers is comforting, the insignificant results for horizontal mergers diminishes even further any confidence in the weak initial findings concerning the impact of investigations on Relative-Horizontals. Second, the conditional probability of applying an antitrust action (Challenge-Rate) has a robust negative impact on horizontal mergers, and seems to have no significant impact on non-horizontal mergers. This result underscores the robustness of the Challenge-Rate variable, as increasing the conditional probability that investigations actually lead to antitrust actions appears to significantly reduce the number of horizontal mergers in both relative (Table 4) and absolute (Table 5) terms, while not affecting the number of non-horizontal mergers (Table 6). Third, the prohibition-rate is insignificant - as it was with relative-horizontal merger activity - in both the

\footnotetext{
${ }^{25}$ First, the Sargan test of over-identifying restrictions yields evidence in all GMM estimations that one cannot reject the hypothesis of no correlation between instruments and error terms. Second, the null hypothesis of no second order autocorrelation on the error differences cannot be rejected, thus suggesting that serial autocorrelation does not exist in the error terms (see regressions’ \#3 \& \#4 in Tables 5 and 6). The R-squared for the fixed effects regressions is .74 and .69 respectively (see regressions \#1 in Tables 5 and 6).
} 
'horizontal' and 'non-horizontal' merger specifications. Fourth, the court-win-rate is insignificant - as it was with relative-horizontal merger activity - in both the 'horizontal' and 'non-horizontal' merger specifications. Fifth, the loss-rate is insignificant in the non-horizontal merger equations (Table 6), but significant (and positive) in the two GMM estimations for the 'horizontal' mergers specification (Table 5). Thus, these results yield some tentative support for the idea that DOJ/FTC court-losses lead to more horizontal mergers in subsequent years. The consistent insignificance of all five deterrence variables on the non-horizontal merger equations is notable as it conforms to the received wisdom that U.S. antitrust authorities are generally unconcerned about non-horizontal transactions; thus, the proclivity of firms to engage in non-horizontal merger activity does not appear to be a function of merger policy tendencies.

With the above in mind, we can summarize the results for the five deterrence variables with respect to 'relative-horizontal' and 'horizontal' merger activity in subsequent years. First, the probability of investigating mergers (Investigation-Rate) indicates a statistically-weak negative impact on the future ratio of horizontal to total mergers; yet, this negative relationship cannot be traced back when dismantling this composition-based deterrence effect into horizontal and non-horizontal mergers. Second, the conditional probability of applying an antitrust action given an investigation (Challenge-Rate) has a robust negative impact on the future ratio of horizontal to total mergers - a deterrence effect that can be traced back to having a stronger negative impact on future horizontal mergers and having no significant impact on non-horizontal mergers. The conditional probability of applying relatively more prohibitions given that an antitrust action is employed (Prohibition-Rate) does not robustly impact both the relative and absolute number of proposed horizontal mergers. The conditional probability of antitrust authorities eliciting a court-win (court-win-rate) has neither a robust impact on 'relative horizontal' nor 'horizontal' merger activity. The conditional probability of antitrust authorities eliciting a court-loss (court-loss-rate) has a statistically weak positive impact on 'horizontal' mergers, but no impact on 'relative-horizontal' mergers. 


\section{Conclusion}

The deterrence effect of merger policy is a topic of significant importance, but has generally gone under-studied by law and economics researchers. We attempt to address this deficiency by employing the established methodological approach from the crime-and-punishment literature and adapting it to a merger-policy setting. In particular, we investigate whether the future composition of proposed merger activity is deterred by the conditional probabilities of investigations (the number of second request investigations relative to proposed horizontal mergers), challenges (the number of antitrust actions - prohibitions and remedies - relative to the number of investigations), prohibitions (the number of prohibitions relative to the total number of antitrust actions), court-wins (the number antitrust-authority favoring verdicts relative to the number of lagged prohibitions), and court-losses (the number of antitrustauthority countering verdicts relative to the number of lagged prohibitions). Accordingly, we bring empirical evidence to bear on this issue by building a cross-industry data set spanning the 1986-1999 period that is composed of measures for U.S. M\&A activity, for U.S. merger policy, and for industry control variables capturing merger-wave drivers. Our data are sufficiently rich and detailed to allow consideration of whether changes in the relevant conditional probabilities for merger policy enforcement impact both the composition of future merger notifications (the relative number of horizontal mergers) and the frequency of future merger notifications (the absolute number horizontal and non-horizontal mergers).

With regards to the composition of future mergers, we find the conditional probability of eliciting an antitrust action (Challenge-Rate) by U.S. antitrust authorities to have a robust negative impact on the relative number of horizontal mergers in subsequent years. We also find some weak evidence suggesting that the probability of eliciting an investigation (InvestigationRate) might also deter future 'relative-horizontal' mergers. However, the conditional probability of eliciting a prohibition with respect to an antitrust action (Prohibition-Rate) does 
not appear to entail significant composition-based deterrence effects. It should be clarified, however, that the lack of statistical significance for the prohibition-rate variable does not mean that prohibitions do not entail deterrence - they do - but only that their deterrence is not statistically different than that of remedies. The conditional probabilities of antitrust authorities eliciting a court win (court-win-rate) or a court loss (court-loss-rate) also indicate a lack of statistical significance when it comes to 'relative-horizontal' merger activity.

With regards to the frequency of future mergers, we find the conditional probability of eliciting an antitrust action (Challenge-Rate) by U.S. antitrust authorities to also have a robust negative impact on the absolute number of horizontal mergers in subsequent years.

Accordingly, the robustness of the Challenge variable is confirmed in the frequency-based regression specifications. Furthermore, we find some evidence that the conditional probability of antitrust authorities eliciting an unfavorable ruling (court-loss-rate) leads to greater levels of absolute 'horizontal' merger activity in subsequent years. Yet, the probability of eliciting an investigation (Investigation-Rate) - as well as the conditional probability of eliciting a prohibition (Prohibition-Rate) and the conditional probability of antitrust authorities eliciting a favorable ruling (court-win-rate) - do not significantly impact the absolute number of 'horizontal' mergers in subsequent years. It is the investigation-rate's lack of significance that is most relevant, as the weak effect of investigations on 'relative-horizontal' merger activity is cast in greater doubt when one realizes that investigations have no significant impact on absolute 'horizontal' merger activity.

Our empirical results indicate that the composition of horizontal merger activity is to some extent negatively influenced by past antitrust investigations, but is even more influenced by the application of past antitrust actions. Our ability to show that the conditional probability of eliciting an antitrust action (Challenge) deters future horizontal merger activity both in relative and absolute terms suggests that the application of antitrust actions involves a robust deterrence effect. Thus, implying that higher antitrust activity in a particular industry sector 
reduces the number of 'potential' anti-competitive mergers in that sector - when making the reasonable assumption that anti-competitive mergers are a subset of horizontal mergers. Accordingly, we tend to agree with the FTC when it notes that its merger challenges yield additional benefits in "demonstrating to the business and legal communities that the agency can and will successfully take legal action to block anticompetitive transactions. This deterrent effect prevents many anticompetitive mergers and acquisitions from ever being proposed” (in Nelson and Sun 2001, 940).

Furthermore, our empirical results suggest that while both prohibitions and remedies involve deterrence, there is no significant difference between the two antitrust actions with respect to deterrence; i.e., prohibitions do not involve significantly more deterrence than do remedies. Such findings are comforting when one recognizes that over the last fifteen years there has been an increasing tendency in the U.S. to employ remedies as a substitute for prohibitions in the case of anti-competitive mergers. The equivalence between remedies and prohibitions suggests then that the proclivity to increasingly employ remedies as an instrument for U.S. merger policy has not come at the expense of diminished deterrence.

The empirical findings here concerning merger policy deterrence can also be linked back to the general results in the empirical literature concerning crime-and-punishment deterrence. We find that eliciting some type of punishment from the antitrust authority involves a deterrence effect, yet the severity of this punishment (prohibitions versus remedies) does not appear to enhance deterrence. This result conforms to Mathur’s (1978) investigation of deterrence, as he found the probability of punishment (versus the severity of punishment) to be a far greater deterrent to overall criminal activity. Moreover, Becker $(1968,176)$ notes that "a common generalization ... is that a change in the probability [of conviction] has a greater effect on the number of offenses than a change in the punishment”. Accordingly, our results concerning merger policy deterrence appear to conform with some of the previous findings in the economics of crime literature. 
The general insignificance of the court-win-rate and court-loss-rate variables (the conditional probabilities of US antitrust winning and losing in court) with regard to future merger activity is also a point worth elaborating upon. In particular, our results suggest that it is more the intentions (intended actions in the form of challenges) of antitrust authorities - and less the validation or repudiation of these actions by the courts - which is integral to deterrence. That said, we should caution that our data set involves far more observations of investigations, remedies and prohibitions than it does of court-case verdicts via the appeals process.

Lastly, given that there does not seem to be a shift towards non-horizontal mergers in the same sector (i.e., the deterrence variables do not encourage acquisitions of target firms by firms from outside the focal industry), it would be interesting to further investigate the impact of heightened antitrust scrutiny. For instance, the application of merger policy instruments in one particular sector could lead to merger activity moving toward other less-scrutinized sectors, or could diminish merger activity in the economy as a whole. We leave this for future work. 


\section{References}

Aaronson, Robin. 1992. “Do Companies take any Notice of Competition policy?,” 2(3) Consumer Policy Review 140-145.

Allen, Bruce T. 1984. "Merger Statistics and Merger Policy,” 1(2) Review of Industrial Organization 78-92.

Andrade Gregor, and Erik Stafford. 2004. "Investigating the Economic Role of Mergers,” 10 Journal of Corporate Finance 1-36.

Avio, Kenneth L. 1988. "Measurement Errors and Capital Punishment," 20 Applied Economics 1253-1262.

Arellano, Manuel, and Stephen Bond. 1991. "Some Tests of Specification for Panel Data: Monte Carlo Evidence and an Application to Employment Equations,” 58 Review of Economic Studies 277-297.

Arellano, Manuel, and Olimpia Bover. 1995. "Another Look at the Instrumental-Variable Estimation of Error-Component Models,” 68 Journal of Econometrics 29-52.

Baker, Jonathan B. 2003. “The Case for Antitrust Enforcement,” 17(4) Journal of Economic Perspectives 27-50.

Banal-Estanol, Albert, Paul Heidhues, Rainer Nitsche, and Jo Seldeslachts. 2011. "Screening and Merger Activity,” Journal of Industrial Economics (forthcoming).

Becker, Gary S. 1968. “Crime and Punishment: An Economic Approach,” 76(2) Journal of Political Economy 169-217.

Berk, Richard. 2005.” New Claims about Executions and General Deterrence: Déjà vu All Over Again?,” 2(2) Journal of Empirical Legal Studies 303-330.

Bertrand, Marianne, Esther Duflo, and Sendhil Mullainathan. 2004. "How much should we trust Differences-in-Differences Estimates?,” 119(1) Quarterly Journal of Economics 249275.

Bond, Stephen. 2002. "Dynamic Panel Data Models: A Guide to Micro Data Methods and Practice,” 1(2) Portuguese Economic Journal 141-162.

Cameron, Samuel. 1988. "The Economics of Crime Deterrence: A Survey of Theory and Evidence,” 41(2): Kyklos 301-323.

Cameron, Samuel. 1994. “A Review of the Econometric Evidence on the Effects of Capital Punishment,” 23(1/2) Journal of Socio-Economics 197-214.

Carlton, Dennis W. and Randal C. Picker. 2006. “Antitrust and Regulation,” Working Paper No. 312. University of Chicago, John M. Olin Law \& Economics.

Cloninger, Dale O., and Roberto Marchesini. 2006. "Execution Moratoriums, Commutations and Deterrence: The Case of Illinois,” 38 Applied Economics 967-973. 
Coate, Malcolm B. 2005. "Empirical Analysis of Merger Enforcement under the 1992 Merger Guidelines,” 27(4) Review of Industrial Organization 279-301.

Coate, Malcolm B., Richard S. Higgins, and Fred S. McChesney. 1990. "Bureaucracy and Politics in FTC Merger Challenges,” 33 Journal of Law and Economics 463-482.

Crandall, Robert W., and Clifford Winston. 2003. "Does Antitrust Policy Improve Consumer Welfare? Assessing the Evidence,” 17(4) Journal of Economic Perspectives 3-26.

Davies, Stephen, and Adrian Majumdar (2002) The Development of Targets for Consumer Savings arising from Competition Policy, Office of Fair Trading Report No. 386, London, UK.

Donohue, John and Justin J. Wolfers. 2005. "Uses and Abuses of Empirical Evidence in the Death Penalty Debate,” 58 Stanford Law Review 791-846.

Deloitte and Touche. 2007. The Deterrent Effect of Competition Enforcement by the OFT. Office of Fair Trading Report No. 962, London, UK.

Dezhbakhsh, Hashem, Paul H. Rubin, and Joanna M. Shepherd. 2003. "Does Capital Punishment have a Deterrent Effect? New Evidence from Postmoratorium Panel Data,” 5(2) American Law and Economics Review 344-376.

Eckbo, B. Espen, and Peggy Wier. 1985. “Antimerger Policy under the Hart-Scott-Rodino Act: A Reexamination of the Market Power Hypothesis,” 28(1) Journal of Law and Economics 119-149.

Eckbo, B. Espen. 1989. “The Role of Stock Market Studies in Formulating Antitrust Policy towards Horizontal Mergers: Comment,” 28 Quarterly Journal of Business and Economics 22-38.

Eckbo, B. Espen. 1992. "Mergers and the Value of Antitrust Deterrence,” 47(3) Journal of Finance 1005-1029.

Ehrlich, Isaac. 1973. "Participation in Illegitimate Activities: A Theoretical and Empirical Investigation,” 81(3) Journal of Political Economy 521-565.

Grogger, Jeffrey. 1990. "The Deterrent Effect of Capital Punishment: An Analysis of Daily Homicide Counts,” 85(410) Journal of the American Statistical Association 295-303.

Golbe, Devra L., and Lawrence J. White 1993. "Catch a Wave: The Time Series Behaviour of Mergers,” 75 Review of Economics and Statistics 493-499.

Gort, Michael. 1969. “An Economic Disturbance Theory of Mergers,” 83 Quarterly Journal of Economics 624-642.

Greene, William. 2004a. "The Behaviour of the Maximum Likelihood Estimator of Limited Dependent Variable Models in the Presence of Fixed Effects," 7(1) Econometrics Journal 98-119. 
Greene, William. 2004b. "Fixed Effects and Bias Due to the Incidental Parameters Problem in the Tobit Model,” 23(2) Econometric Reviews 125-147.

Harford, Jarrod. 2005. “What Drives Merger Waves?,” 77(3) Journal of Financial Economics 529-560.

Joskow, Paul L. 2002. “Transaction Cost Economics, Antitrust Rules, and Remedies.” Journal of Law, Economics and Organization. 18(1): 95-116.

Katz, Lawrence, Steven D. Levitt, and Ellen Shustorovich. 2003. "Prison Conditions, Capital Punishment, and Deterrence,” 5(2) American Law and Economics Review 318-343.

Keele, Luke, and Nathan J. Kelly. 2006. "Dynamic Models for Dynamic Theories: The Ins and Outs of Lagged Dependent Variables,” 14 Policy Analysis 186-205.

Klein, Lawrence R., Brian Forst, and Victor Filatov 1978. The Deterrent effect of Capital Punishment: an Assessment of the Estimates, in A. Blumstein, J. Cohen, and D. Nagin, eds., Deterrence and Incapacitation: Estimating the Effects of Criminal Sanctions on Crime Rates. Washington DC: National Academy of Sciences.

Klevorick, Alvin K. 1995. "The Economic Theory of Crime and the Problems of a Society in Transition,” 2(2) International Journal of the Economics of Business 345-357.

Kwoka, John E. 1999. “Commitment to Competition: An Assessment of Antitrust Agency Budgets since 1970,” 14 Review of Industrial Organization 295-302.

Leary, Thomas B. 2002. “The Essential Stability of Merger Policy in the United States,” 70 Antitrust Law Journal 105-142.

Long, W.F., R. Schramm and R.D. Tollison. 1973. "The Economic Determinants of Antitrust Activity," Journal of Law and Economics 351-364.

Mathur, Vijay K. 1978. "Economics of Crime: An Investigation of the Deterrent Hypothesis for Urban Areas,” 60(3) Review of Economics and Statistics 459-466.

Mocan, H. Naci, and R. Kaj Gittings. 2003. "Getting Off Death Row: Commuted Sentences and the Deterrent Effect of Capital Punishment," 46 Journal of Law and Economics, 453478.

Nelson, Philip, and Su Sun. 2001. "Consumer Savings from Merger Enforcement: A Review of the Antitrust Agencies’ Estimates.” 69 Antitrust Law Journal 921-960.

Passell, Peter, and John B. Taylor. 1977. "The Deterrent Effect of Capital Punishment: Another View,” 67 American Economic Review 445-451.

Preston, W.P. and J.M. Connor. 1992. “An Economic Evaluation of Federal Antitrust Activity in the Manufacturing Industries,” 34 Antitrust Bulletin 969-996.

Rhodes-Kropf, Matthew, David T. Robinson and S. Viswanathan. 2005. "Valuation Waves and Merger Activity: The Empirical Evidence,” 77(3) Journal of Financial Economics 561-603. 
Scherer, Frederic M. 1980. Industrial Market Structure and Economic Performance. Chicago, IL: Rand McNally.

Seldeslachts, Jo, Joseph A. Clougherty, and Pedro P. Barros. 2009. "Settle for Now but Block for Tomorrow: The Deterrence Effects of Merger Policy Tools," 52 Journal of Law and Economics 607-634.

Siegfried, J. J. 1975. “The Determinants of Antitrust Activity,” 18 The Journal of Law and Economics 559-574.

Stigler, George. 1966. “The Economic Effects of the Antitrust Laws,” 9 Journal of Law and Economics 225-258.

Twynstra Gudde. 2005. "Research into the Anticipation of Merger Control.” Report submitted to NMa, October 272005.

Wilks, Stephen. 1996. The Prolonged Reform of United Kingdom Competition Policy, in G. Bruce Doern and Stephen Wilkes, eds., Comparative Competition Policy: National Institutions in a Global Market. Oxford: Clarenden Press.

Zimmerman, Paul R. 2004. "Estimates of the Deterrent Effect of Alternative Execution Methods in the United States: 1978-2000," 65(4) American Journal of Economics and Sociology 909-941.

Zimmerman, Paul R. 2009. "Statistical Variability and the Deterrent Effect of the Death Penalty,” 11(2) American Law and Economics Review 370-398. 